\title{
Experimental investigation of solar photovoltaic panel integrated with phase change material and multiple conductivity-enhancing-containers
}

\author{
Preeti Singh $^{\mathrm{a}, 1}$, Vijay Mudgal ${ }^{\mathrm{b}, 1}$, Sourav Khanna ${ }^{\mathrm{c},{ }^{*}, 1}$, Tapas K. Mallick ${ }^{\mathrm{d}}$, K. S. Reddy

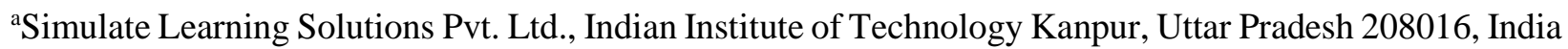 \\ ${ }^{b}$ Heat Transfer and Thermal Power Laboratory, Department of Mechanical Engineering, Indian Institute of \\ Technology Madras, Chennai - 600036, India \\ ${ }^{\text {'S }}$ chool of Energy and Electronic Engineering, University of Portsmouth, Portsmouth, PO1 3DJ, UK \\ ${ }^{\mathrm{d}}$ Environment and Sustainability Institute, University of Exeter, Penryn Campus, Penryn TR10 9FE, UK
}

\begin{abstract}
Among all passive methods for photovoltaics (PV) cooling, phase change material (PCM) can be highly effective due to high latent heat capacity. However, very low thermal-conductivity of PCM restricts its potential. The proposed work focuses on the enhancement of rate of heat transfer from PV to PCM by using conductivity-enhancing-containers. The proposed approach was experimented outdoor and compared with the reference panel for different seasons at Chennai, India. PV temperature, open circuit voltage, short circuit current, Current-Voltage (I-V) and Power-Voltage (P-V) curves, fill-factors, power outputs, efficiency and daily electricity generation are reported. The results show that the proposed heat sink was able to decrease the maximum PV temperature from $64.4^{\circ} \mathrm{C}$ to $46.4^{\circ} \mathrm{C}$ for January and $77.1^{\circ} \mathrm{C}$ to $53.8^{\circ} \mathrm{C}$ for June. It increased the open circuit voltage of PV from $24.3 \mathrm{~V}$ to $26.4 \mathrm{~V}$ for January and $23.6 \mathrm{~V}$ to $26.0 \mathrm{~V}$ for June. The fillfactor increased from 0.678 to 0.705 for January. Consequently, the electrical efficiency increased from $9.5 \%$ to $10.5 \%$ during noon. Daily electricity generation increased from $769 \mathrm{Wh} /$ day to $817 \mathrm{Wh} /$ day during January and $948 \mathrm{Wh} /$ day to $1026 \mathrm{Wh} /$ day during June. Thus, daily electricity generation increased by $6.2 \%$ for January and $8.3 \%$ for June using proposed approach.
\end{abstract}

\section{Keywords}

photovoltaic panel; phase change material; temperature regulation

*Corresponding author, Email: sourav.khanna@port.ac.uk, sourav.khanna1@gmail.com

${ }^{1}$ First Authors 


\section{Introduction}

The energy need and thereby its production have increased all across the world because of better lifestyle, automation and industrialization [1]. Presently, most of the world energy generation is met by conventional sources which are limited and also pollute the environment adversely [2]. To secure future energy demand and save environment, researchers and policy makers all over the world are showing interest towards non-conventional sources [3]. In past few decades, lot of research and investment are being made in the renewable energy resources [4]. Among all renewable sources till date, solar energy is most abundant, clean and inexhaustible source from which electrical energy and thermal energy can be obtained [5]. Solar photovoltaics (PV) are semiconductor devices which directly produce electricity from solar radiation falling over them [6]. However, electricity conversion efficiency of PV depends upon operating temperature of the PV cell. With increase in operating temperature, there is decrease in the energy conversion efficiency [7]. The energy conversion efficiency of PV panel decreases by $0.5 \%$ with per degree Celsius rise in PV temperature [8]. Therefore, to maintain higher efficiency of the PV panel, it is important to maintain lower PV temperature. There are active methods like forced ventilation [9] and water cooling [10] to maintain the temperature of PV panel at lower level. Using active methods can decrease the PV temperature by $30 \mathrm{~K}$ [11]. However, it increases the operation and maintenance cost of the system. Thus, passive methods like natural ventilation, heat sink [12] and thermoelectric cooling [13] are also explored by researchers. One of the effective passive approach to maintain the temperature of the PV panel is the integration of phase change material (PCM) at the backside of the panel [14]. PCM has the ability to absorb/release large amount of heat within small temperature range [15]. Some of the desirable properties of PCM for cooling of PV are high 
latent heat of fusion, congruent melting, high conductivity, non-toxic, non-corrosive and nonsusceptibility to chemical deposition. Paraffin wax based PCMs partially satisfy these properties.

Rezvanpour [16] showed that, with the use of PCM, the surface temperature of the PV panel can be lowered by $13.3 \mathrm{~K}$ on an average. By adding fins inside the PCM, the surface temperature of the PV can be further lowered [17]. It was reported that for fin spacing of $12 \mathrm{~mm}$, there was optimum conduction/convection effect which improved the performance of PV panel [18]. However, the study was conducted for vertical system. The influence of tilt angle on the performance was investigated by Rabie et al. [19]. The results showed that the PV temperature can be lowered by keeping the PCM chamber tilted $\left(45^{\circ}\right)$. Souayfane et al. [20] presented a simplified model to analyze the energy/momentum/mass conservation equations of PCM. It was found that the simplified model can estimate the results of liquid fraction with $94 \%$ accuracy. The effect of microencapsulated PCM on the PV performance has also been investigated [21]. The results show an increase in efficiency of PV-PCM panel by $2.01 \%$ compared to reference panel. In order to enhance the performance of PCM based cooling, nanoparticle enriched PCMs were inspected using aluminium oxide [22], copper oxide [23], silicon dioxide [23], graphite [24], copper foam [24], metallic fibre [25] and Boehmite [26]. It must be mentioned that the nano-particles enhanced PCM was synthesized in laboratory and not available in market.

From literature review, it has been observed that due to low thermal conductivity of PCM, efforts are required to increase the heat transfer within the PCM and from PV to PCM. In the present work, multiple conductivity-enhancing-aluminium containers were investigated to increase the heat transfer. A commercially and widely available PCM was used for the PV cooling. The performance of proposed system has been experimentally analysed under outdoor conditions for different seasons at Chennai, India. 


\section{Experimental investigation and Instrumentation}

The experimentation involves usage of following test setup, instruments and materials

(i) PV panels: Two monocrystalline silicon based PV panels (175Wp rating) were used for the investigation. Prior to actual experiment, both panels were characterized outdoor under solar radiation for two clear weather days. For both panels, power output, open circuit voltage and short circuit current were measured to assure the consistency among the PV panels. The deviations in the respective parameters were found to be less than $1 \%$. The specifications of PV panels considered for the experiments are listed in Table 1.

Table 1: Specifications of photovoltaic panels [27]

\begin{tabular}{lll}
\hline Parameter & Unit & Value \\
\hline Maximum power rating $\left(\mathrm{P}_{\mathrm{max}}\right)$ & $\mathrm{W}$ & 175 \\
Open circuit voltage $\left(\mathrm{V}_{\mathrm{oc}}\right)$ & $\mathrm{V}$ & 29.8 \\
Short circuit current $\left(\mathrm{I}_{\mathrm{sc}}\right)$ & $\mathrm{A}$ & 8.29 \\
Voltage at maximum power $\left(\mathrm{V}_{\mathrm{mp}}\right)$ & $\mathrm{V}$ & 23.2 \\
Current at maximum power $\left(\mathrm{I}_{\mathrm{mp}}\right)$ & $\mathrm{A}$ & 7.55 \\
Fill factor & $\%$ & 70.8 \\
Panel efficiency & $\%$ & 13.5 \\
\hline
\end{tabular}

(ii) Aluminum containers: Eleven containers with external dimensions of $960 \mathrm{~mm}$ (width), $100 \mathrm{~mm}$ (height) and 45mm (depth) were fabricated with aluminum alloy (1050A) having thickness of $3 \mathrm{~mm}$. The width of the container was almost same as the width of PV back. In order to choose the height of the containers, simulations were carried out for various heights such as $1 \mathrm{~m}, 1 / 2 \mathrm{~m}, 1 / 3 \mathrm{~m}, 1 / 4 \mathrm{~m}, 1 / 5 \mathrm{~m}$ and $1 / 6 \mathrm{~m}$. The results for the average temperature of the PV and the temperature of the whole PV-PCM system are plotted in Figs. 1 and 2 respectively. The results show that as the height of the containers decreases, the average temperature of the PV decreases. It is due to the fact that the decrease in the 
height of the containers leads to increase in the number of containers at the PV back which increases the contact surface area of PCM with aluminium resulting in increased rate of heat transfer. It can be seen that as the height of the container approaches to $1 / 6 \mathrm{~m}$, there is no further significant drop in PV temperature. Thus, the containers with height around $1 / 6 \mathrm{~m}$ were chosen (subject to availability). The optimized depth of the container was chosen from the previous study [28].

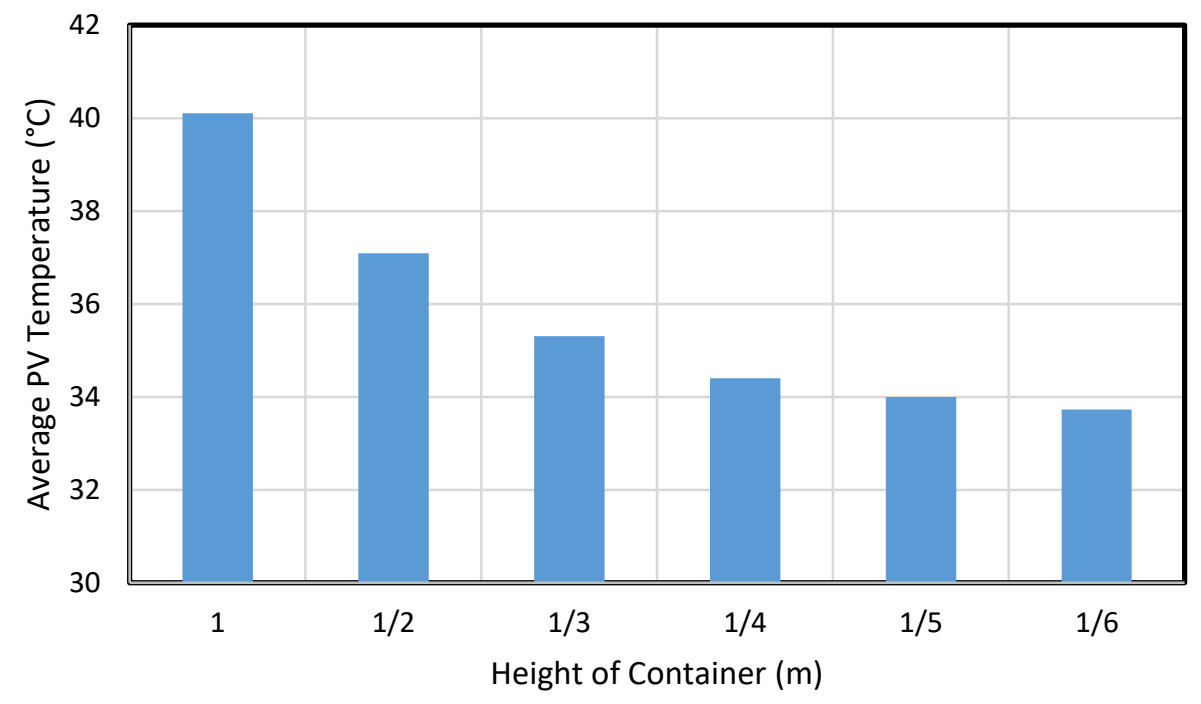

Fig. 1. Average temperature of PCM cooled PV panel at the end of 3 hour simulation for various heights of PCM containers 


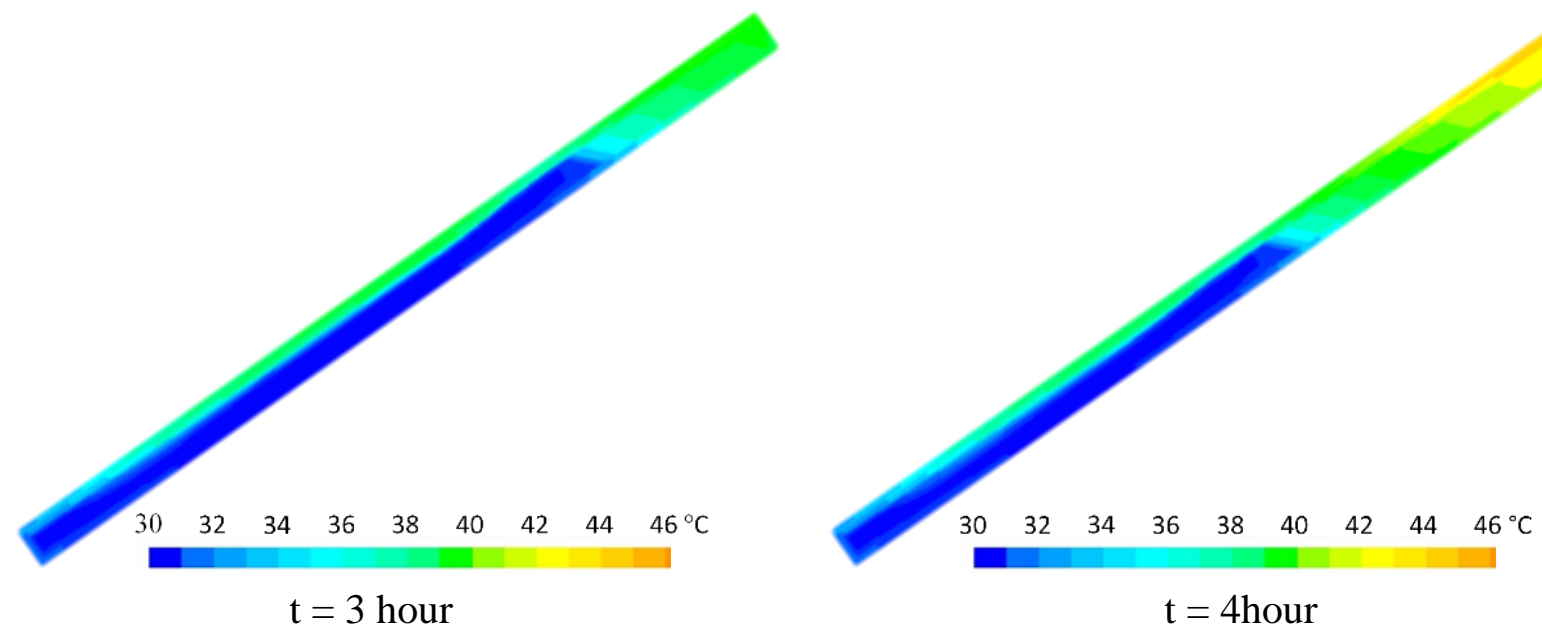

(i) Height of container $=1 \mathrm{~m}$

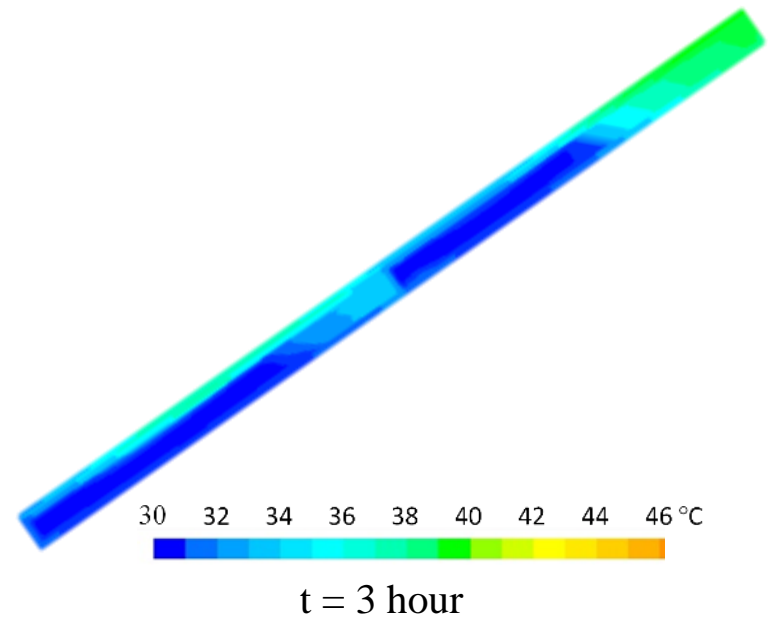

(ii) Height of containers $=1 / 2 \mathrm{~m}$
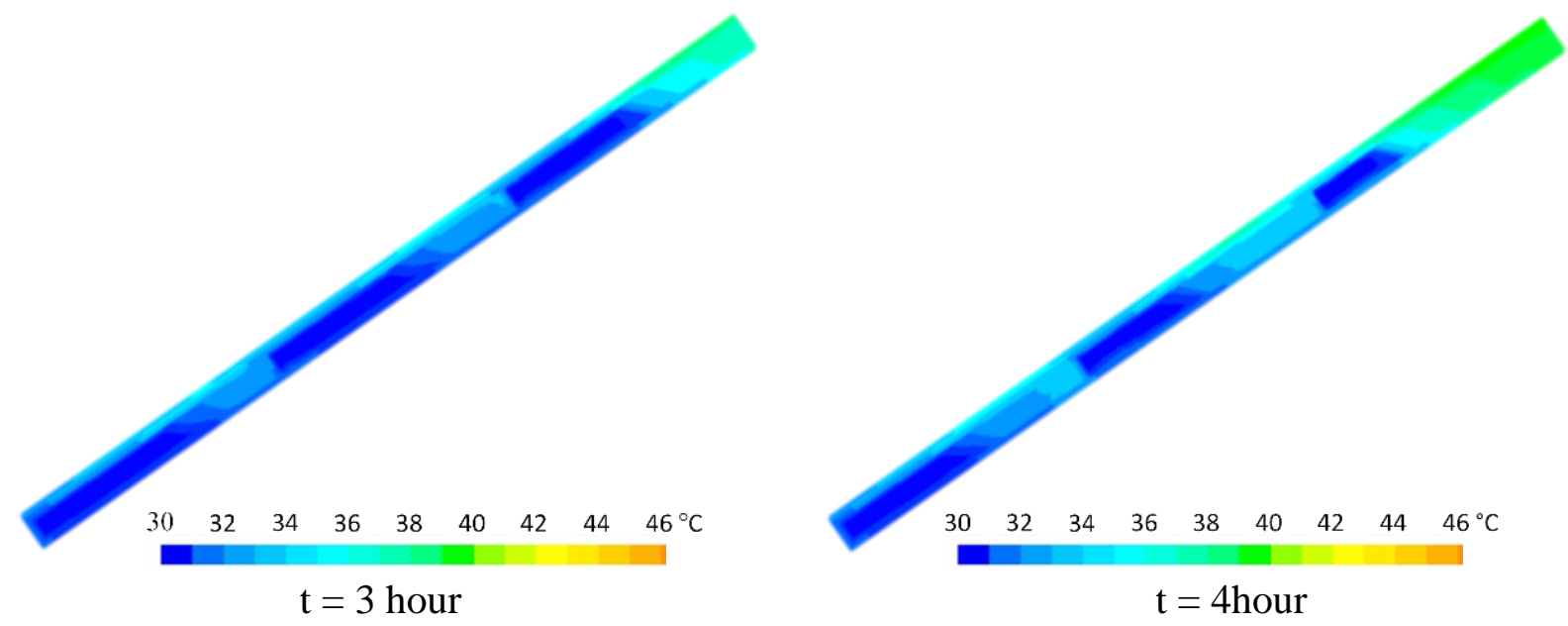

(iii) Height of containers $=1 / 3 \mathrm{~m}$ 

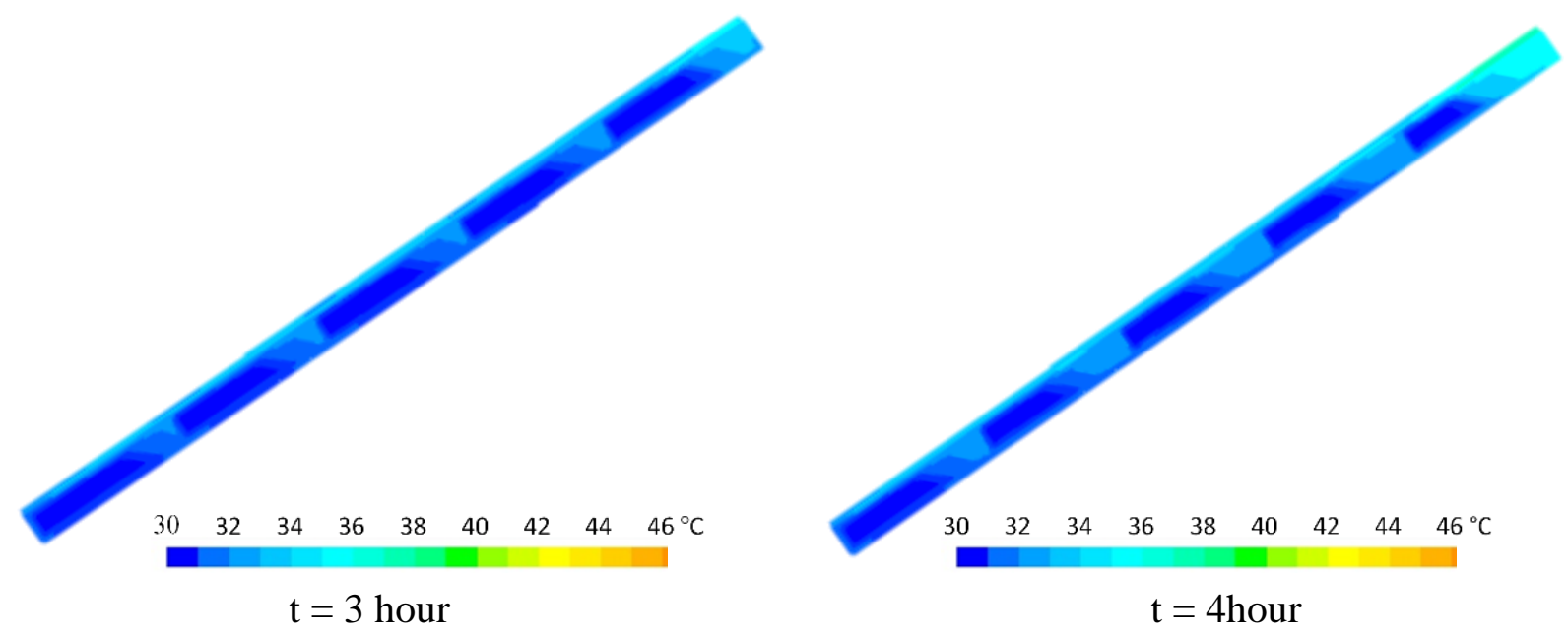

(iv) Height of containers $=1 / 5 \mathrm{~m}$
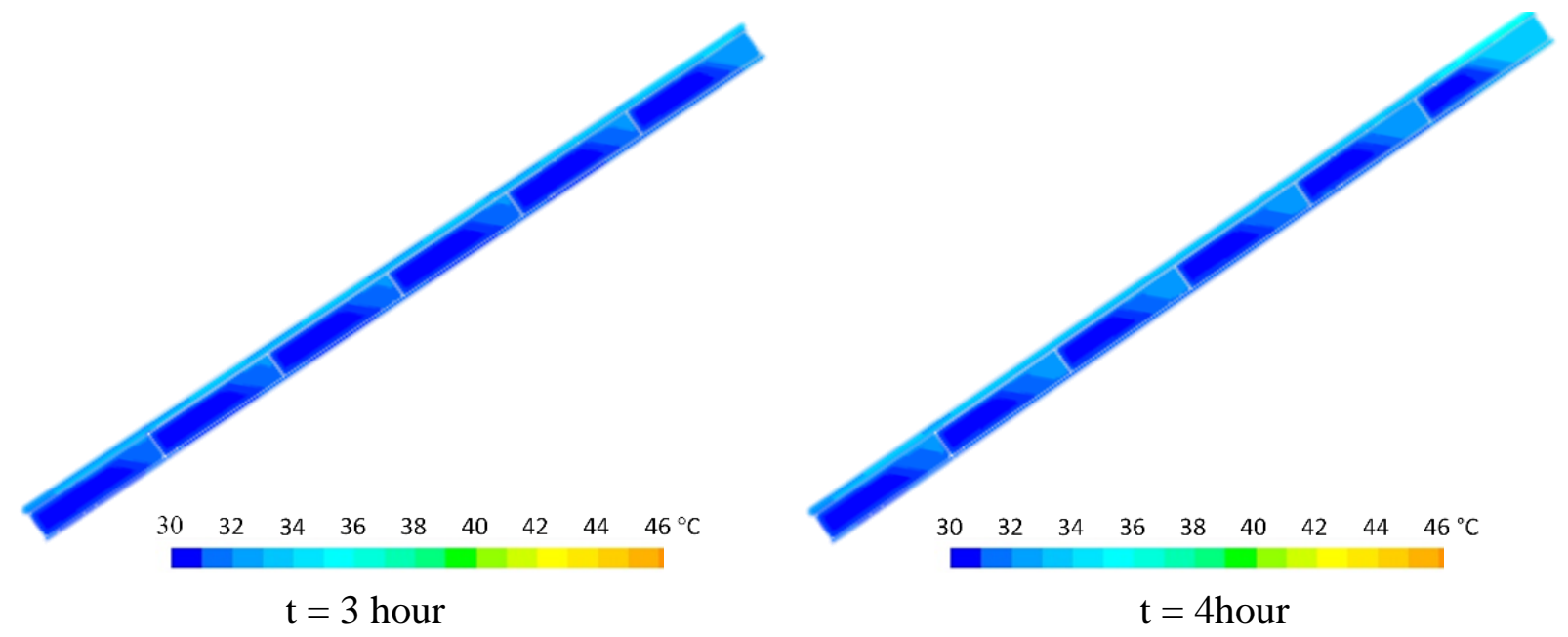

(v) Height of containers $=1 / 6 \mathrm{~m}$

Fig. 2. Temperature of PCM cooled PV system for various heights of PCM containers

The fabricated aluminum containers of aforementioned dimensions were integrated at the back of one panel with heat sink paste. The PV panel and containers were further tightened with clamps throughout to have better thermal contact between panel back surface and aluminum containers. Expansion tubes were attached with all containers for the provision of expansion of PCM during melting. Schematic diagram and photographic view of PV panel with aluminum containers at the back side of PV are shown in Figs. 3 (a) and 3 (b) respectively. 


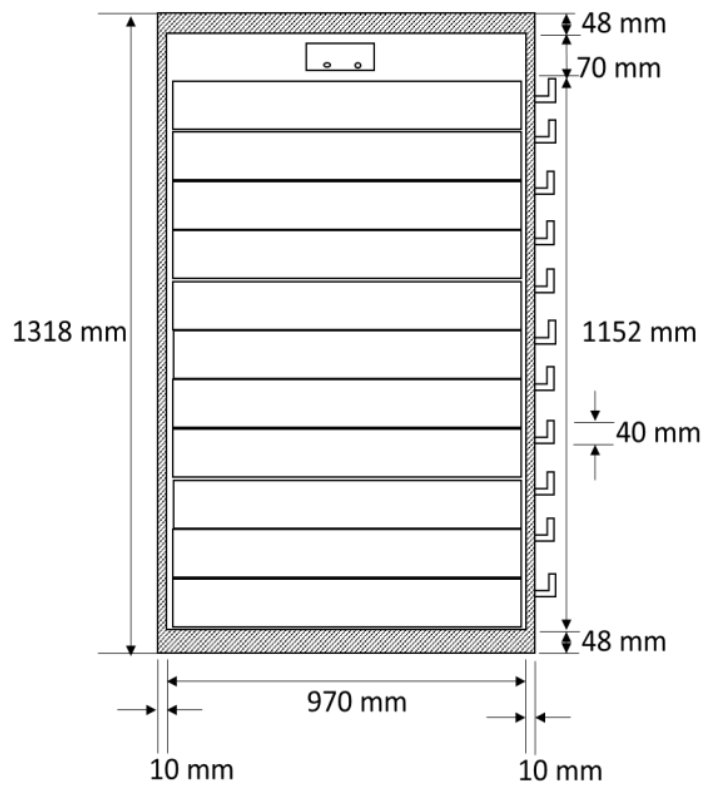

(a)

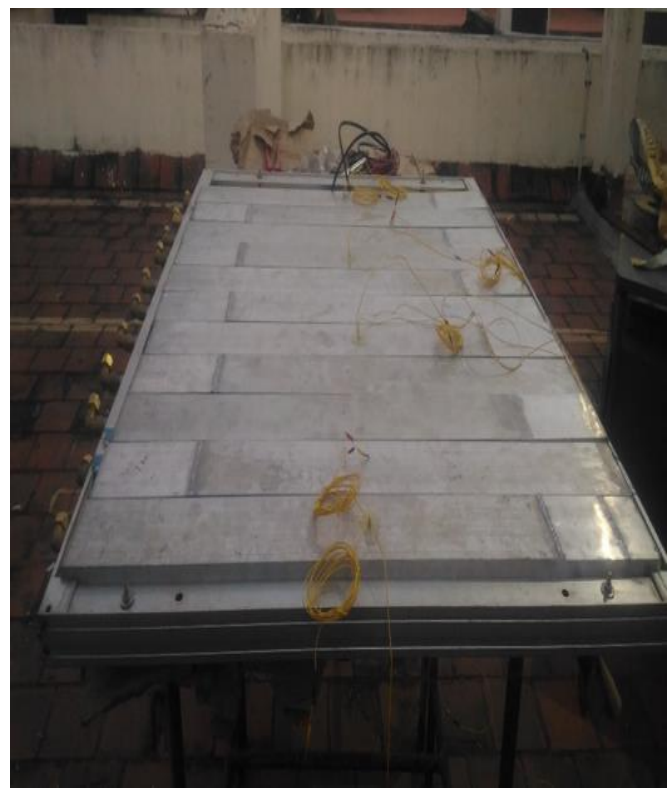

(b)

Fig.3. PV panel with aluminum containers attached at back surface (a) Schematic view (b) Photographic view

(iii) Electronic load controller: Two calibrated electronic load controllers [29] (makeProdigit model- 3311F) were used to measure open circuit voltage $\left(\mathrm{V}_{\mathrm{oc}}\right)$, short circuit current $\left(\mathrm{I}_{\mathrm{sc}}\right)$ and maximum power output $\left(\mathrm{P}_{\max }\right)$ of both $\mathrm{PV}$ ref and $\mathrm{PV} \mathrm{pcm}_{\mathrm{pm}}$ panels.

(iv) Thermocouples: To measure the temperatures of $\mathrm{PV}_{\text {ref }}$ and $\mathrm{PV}_{\mathrm{pcm}}$ panels and $\mathrm{PCM}$ temperature inside the aluminum containers, total sixteen calibrated K-type thermocouples were used. Fig. 4 shows the locations of the thermocouples on the photovoltaic panel and inside the aluminium containers. Leakage after placing thermocouples inside the containers was prevented by araldite epoxy glue. 


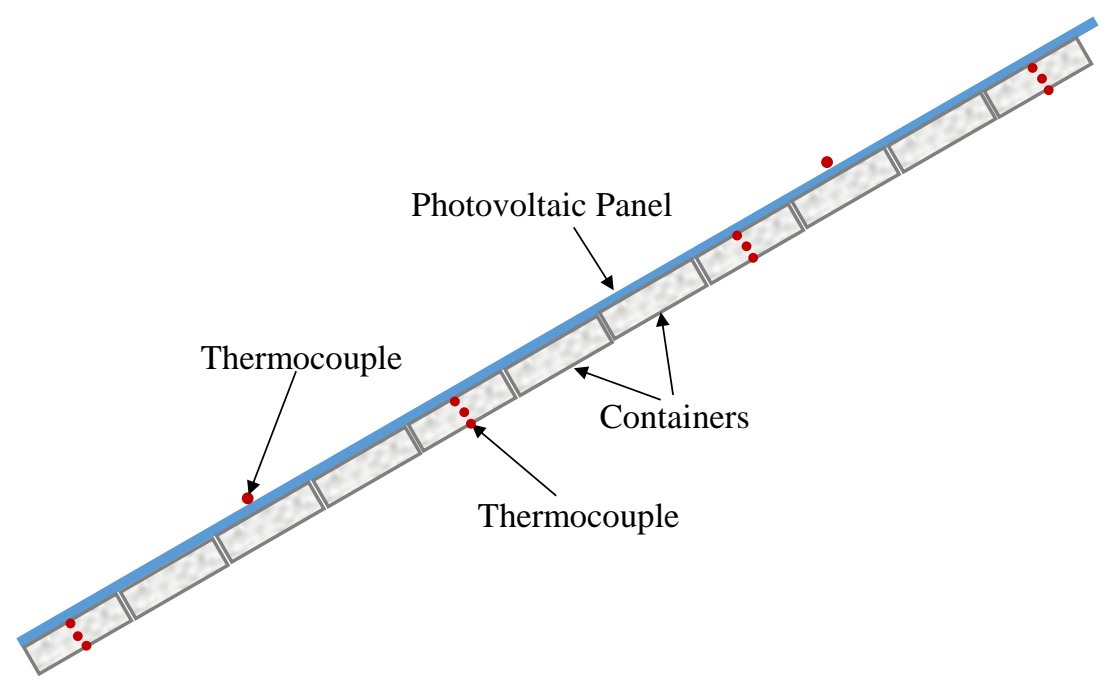

Fig 4. Locations of thermocouples marked by dots

(v) Pyranometer: The solar radiation was measured by a calibrated pyranometer (makeKipp and Zonen Delft, model- CM11). The sensitivity of the pyranometer is $4.96 \times 10^{-6}$ $\mathrm{V} / \mathrm{Wm}^{-2}$. The pyranometer was kept on tilted surface (having tilt angle same as that of PV panel) to measure the irradiance received by the PV panels.

(vi) Data acquisition system: Keithley Integra series, model - 2700 multimeter data acquisition system was connected with computer to record the readings of thermocouples. The data logger is a 40 channel differential multiplexer, used to connect thermocouples. The data measurement is in digital form which convert temperature readings from $\mathrm{mV}$ to ${ }^{\circ} \mathrm{C}$.

(vii) Phase change material: Calcium chloride hexahydrate $\left(\mathrm{CaCl}_{2} \cdot 6 \mathrm{H}_{2} \mathrm{O}\right)$ was used as phase change material for the study which has relatively higher thermal conductivity than others. The thermo-physical properties of the PCM are listed in Table 2. 
Table 2: Thermo physical properties of studied PCM - Calcium chloride hexahydrate $\mathrm{CaCl}_{2} .6 \mathrm{H}_{2} \mathrm{O}$

\begin{tabular}{lll} 
Thermophysical properties & Units & Specifications \\
\hline Melting point & ${ }^{\circ} \mathrm{C}$ & 30 \\
Heat of fusion & $\mathrm{kJ} \mathrm{kg}^{-1}$ & 191 \\
Thermal conductivity & $\mathrm{W} \mathrm{m}{ }^{-1} \mathrm{C}^{-1}$ & 1.08 \\
Density & $\mathrm{kg} / 1$ & 1.71 \\
Specific heat capacity & $\mathrm{kJ} \mathrm{kg}^{-1} \mathrm{C}^{-1}$ & 1.4 \\
Kinematic viscosity & $\mathrm{m}^{2} \mathrm{~s}^{-1}$ & $1.84 \times 10^{-3}$ \\
Thermal expansion coefficient & ${ }^{\circ} \mathrm{C}^{-1}$ & $5.0 \times 10^{-4}$ \\
\hline
\end{tabular}

(viii) Thermal conductive paste: The space between the PV panel back side and aluminium containers was filled with thermal conductive paste. The conductive paste exterminates the air gap between all the containers and the PV panel. It enhances the dissipation of heat and heat transfer from PV panel to aluminium containers. The specifications of the thermal conductive paste used for the study are listed in Table 3.

Table 3. Thermophysical specifications of thermal conductive paste [30]

\begin{tabular}{lll}
\hline Thermophysical properties & Units & Specifications \\
\hline Brand name & - & Buyyart (model DRG-102) \\
Thermal conductivity & $\mathrm{W} \mathrm{m}^{-1} \mathrm{~K}^{-1}$ & $4-5$ \\
Composition & - & Silver, Carbon \\
Color & - & Grey \\
General description & - & non-corrosive, non-toxic, non-volatile \\
\hline
\end{tabular}




\section{Experimentation Location and Procedure}

\subsection{Experiment location}

The experiments were carried out at solar energy research laboratory at Indian institute of technology Madras, Chennai, India $\left(13.01^{\circ} \mathrm{N}\right.$ and $\left.80.24^{\circ} \mathrm{E}\right)$. The highest ambient temperature was during the month of June whereas the lowest temperature was during the month of January. The experiments were conducted during two different weather seasons (January and June). The experiment location was not affected by any shading throughout the day. The solar irradiance and ambient temperature are given in Fig. 5.

\subsection{Experiment procedure}

For experimentation, $\mathrm{PV}_{\text {ref }}$ and $\mathrm{PV}_{\mathrm{pcm}}$ panels were placed outside in sun exposure. The experiments were conducted on clear weather day on $26^{\text {th }}$ Jan 2019 and $15^{\text {th }}$ June 2019 from 7:00 am to 6:00 pm as shown in Fig. 6 and Fig. 7 respectively. Both the panels and pyranometer were inclined at an angle of $13^{\circ}$ facing south direction. The terminals of panels were connected to electronic load controllers and operated in MPPT mode. The measurements for power outputs, open circuit voltages, short circuit currents and temperatures at different points of both the panels, solar irradiance and ambient temperature were recorded at time intervals of 20 minutes.

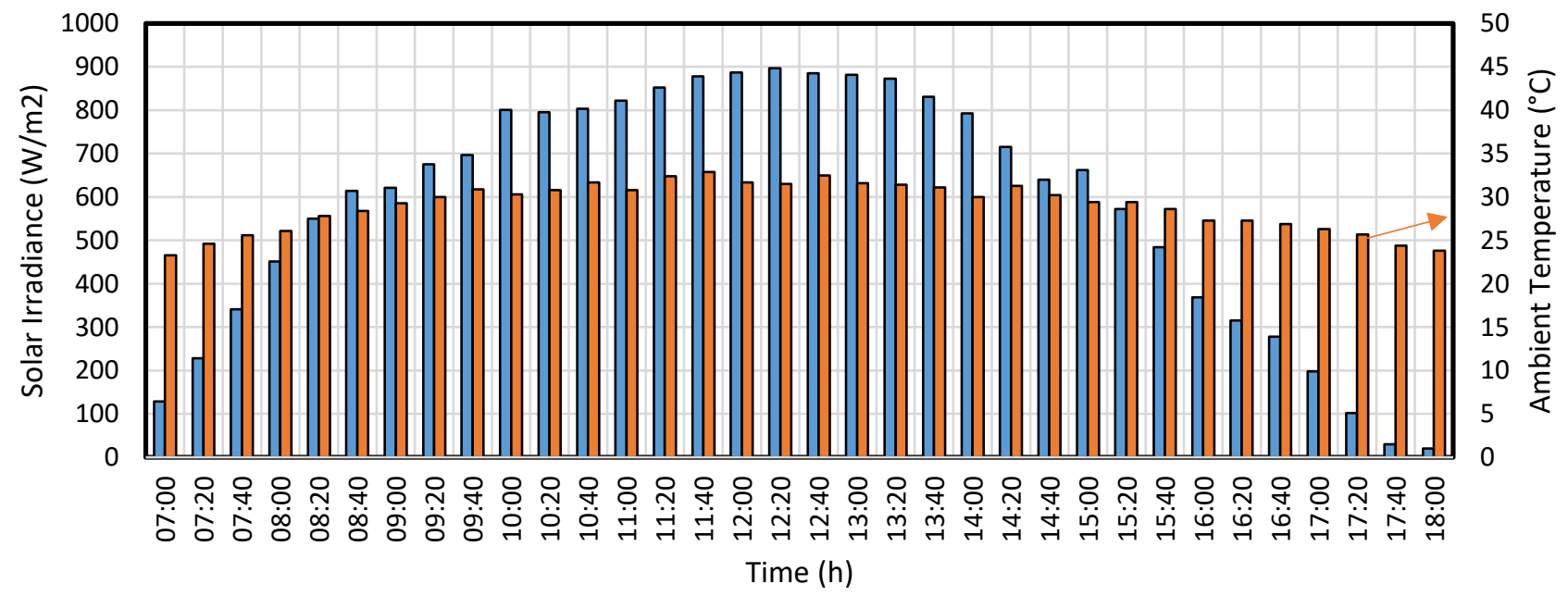

(a) January 


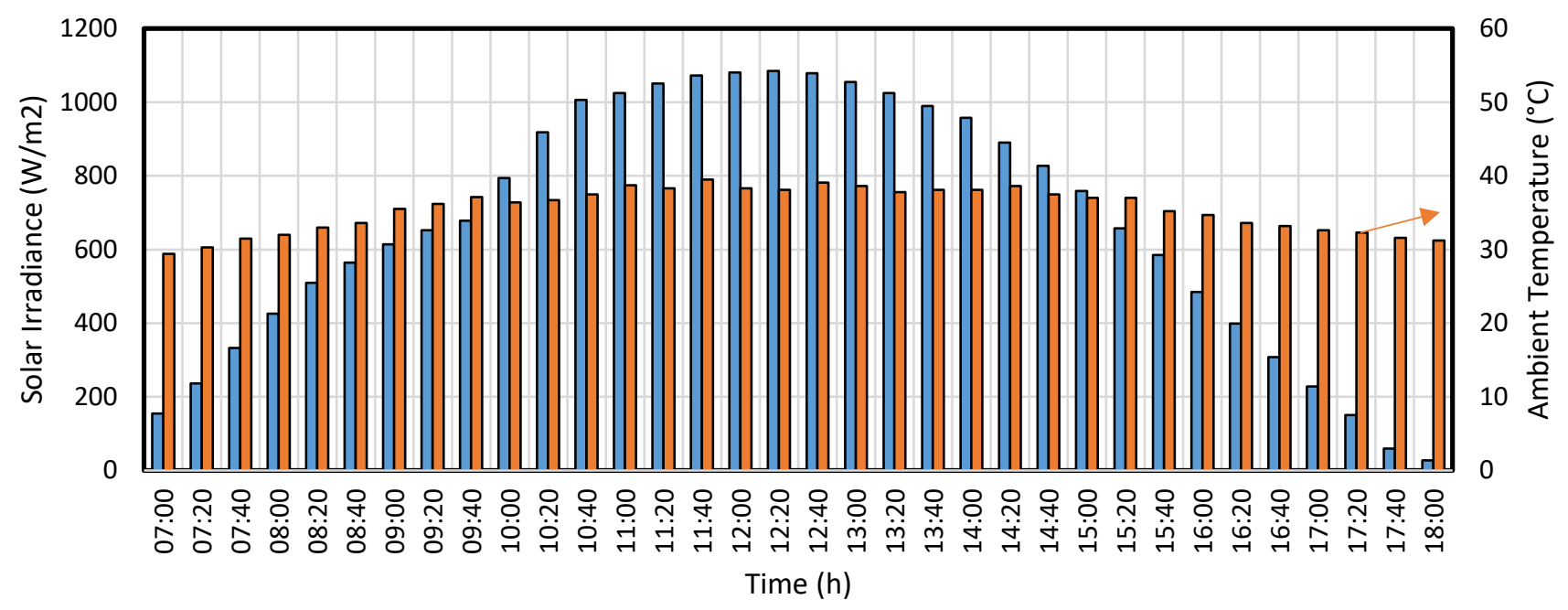

(b) June

Fig. 5. Solar irradiance and ambient temperature

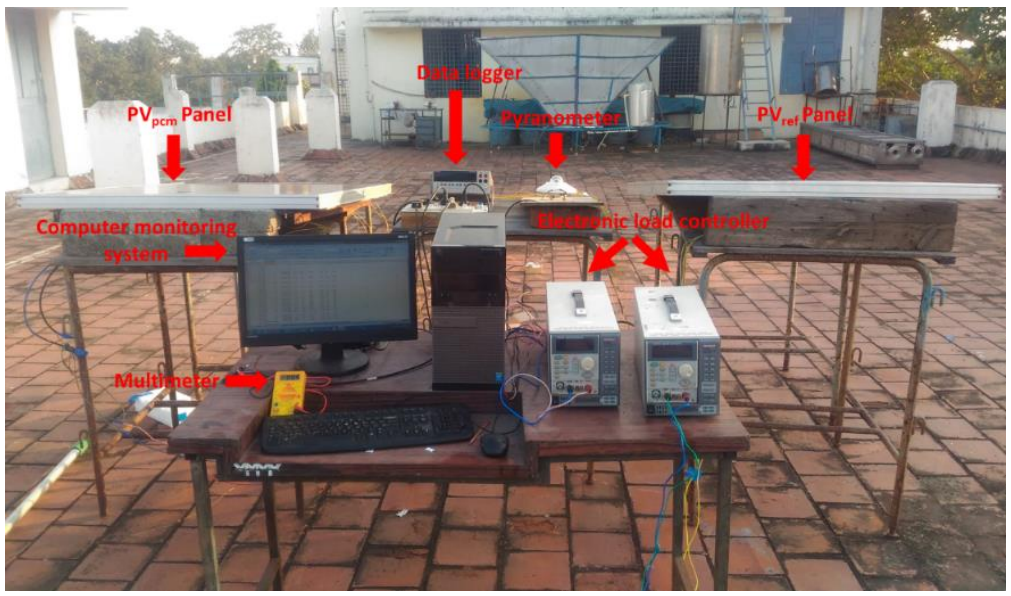

Fig. 6. Photographic view of experiment conducted in the month of January
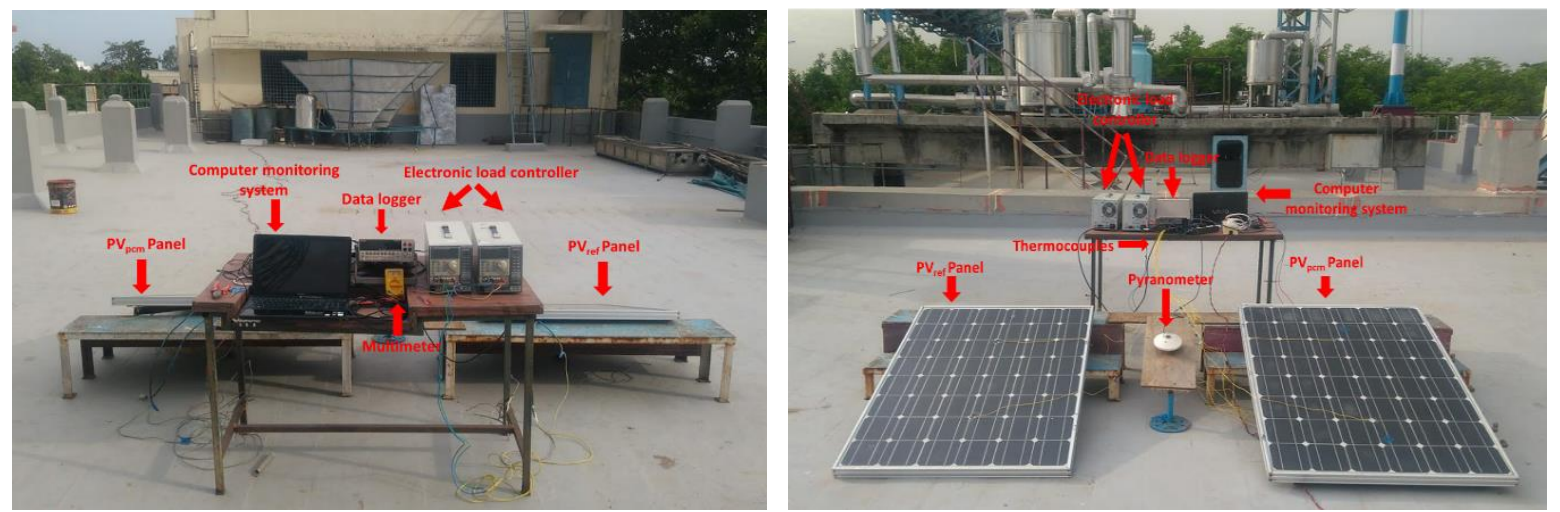

Fig. 7. Photographic view of experiment conducted in the month of June 


\subsection{Uncertainty analysis}

In order to assure that the experiment results are measured correctly, it is important to report the measurement error. The uncertainties in the measured parameters of the measuring devices are listed in Table 4. The uncertainty in the measurements of solar radiation $(S)$, open circuit voltage $\left(V_{O C}\right)$, short circuit current $\left(I_{S C}\right)$, maximum power point $\left(P_{\max }\right)$ and temperature $(T)$ are found to be $1.80 \%, 1.05 \%, 1.05 \%, 1.05 \%$ and $1.16 \%$ respectively. The resulted uncertainty in the values of electrical efficiency $(\eta)$ and fill factor $(F F)$ are $2.08 \%$ and $1.82 \%$ which are calculated using following equations.

$$
\begin{aligned}
& \frac{d \eta}{\eta} \times 100=\sqrt{\left[\left(\frac{d P_{\max }}{P_{\max }} \times 100\right)^{2}+\left(\frac{d S}{S} \times 100\right)^{2}\right]} \\
& \frac{d F F}{F F} \times 100=\sqrt{\left[\left(\frac{d P_{\max }}{P_{\max }} \times 100\right)^{2}+\left(\frac{d V_{O C}}{V_{O C}} \times 100\right)^{2}+\left(\frac{d I_{S C}}{I_{S C}} \times 100\right)^{2}\right]}
\end{aligned}
$$

Table 4. Uncertainty in measured values

\begin{tabular}{lll}
\hline Instrument & Measured value & Uncertainty \\
\hline Pyranometer & Solar radiation & $1.80 \%$ \\
Electronic load controller & $\mathrm{P}_{\max }, \mathrm{V}_{\mathrm{oc}}, \mathrm{I}_{\mathrm{sc}}$ & $1.05 \%$ \\
Thermocouple & Temperature & $1.16 \%\left(0.9^{\circ} \mathrm{C}\right)$ \\
\hline
\end{tabular}




\section{Results and Discussion}

In this section, the performances of $\mathrm{PV}_{\text {ref }}$ and $\mathrm{PV}_{\mathrm{pcm}}$ panels are compared in terms of temperature of the panel, open circuit voltage, short circuit current, Current-Voltage (I-V) and Power-Voltage (P-V) curves, fill factors, power output, electrical efficiency and daily electricity generation.

\subsection{Average temperature of PV panels}

The variations in the temperatures of the reference PV panel and PCM cooled PV panel from 7:00 hrs to 18:00 hrs for the month of January and June are shown in Figs. 8 (a) and 8 (b) respectively. It can be observed from the figures that the average temperatures of both the panels increase with increase in solar intensity, reach maximum value and thereafter decrease with decrease in solar intensity which can also be seen from the results of Huang et al. [18]. It is because of the fact that the elevation in the solar irradiance increases the heat generation in the cells which increases the cell temperature. The figure shows that the maximum temperature attained by the PCM cooled panel is delayed compared to the maximum temperature attained by the normal panel. The peak temperatures of PV-ref and PV-pcm panels for January and June months are shown in Fig. 9. The maximum temperatures attained by the reference and PCM cooled panels for the month of January are $64.4^{\circ} \mathrm{C}$ and $46.4^{\circ} \mathrm{C}$ respectively. For the month of June, the maximum temperatures attained by the reference and PCM cooled panels are $77.1^{\circ} \mathrm{C}$ and $53.8^{\circ} \mathrm{C}$ respectively. The reduction in PV panel temperature is achieved using phase change material with multiple conductivity-enhancingcontainers. 


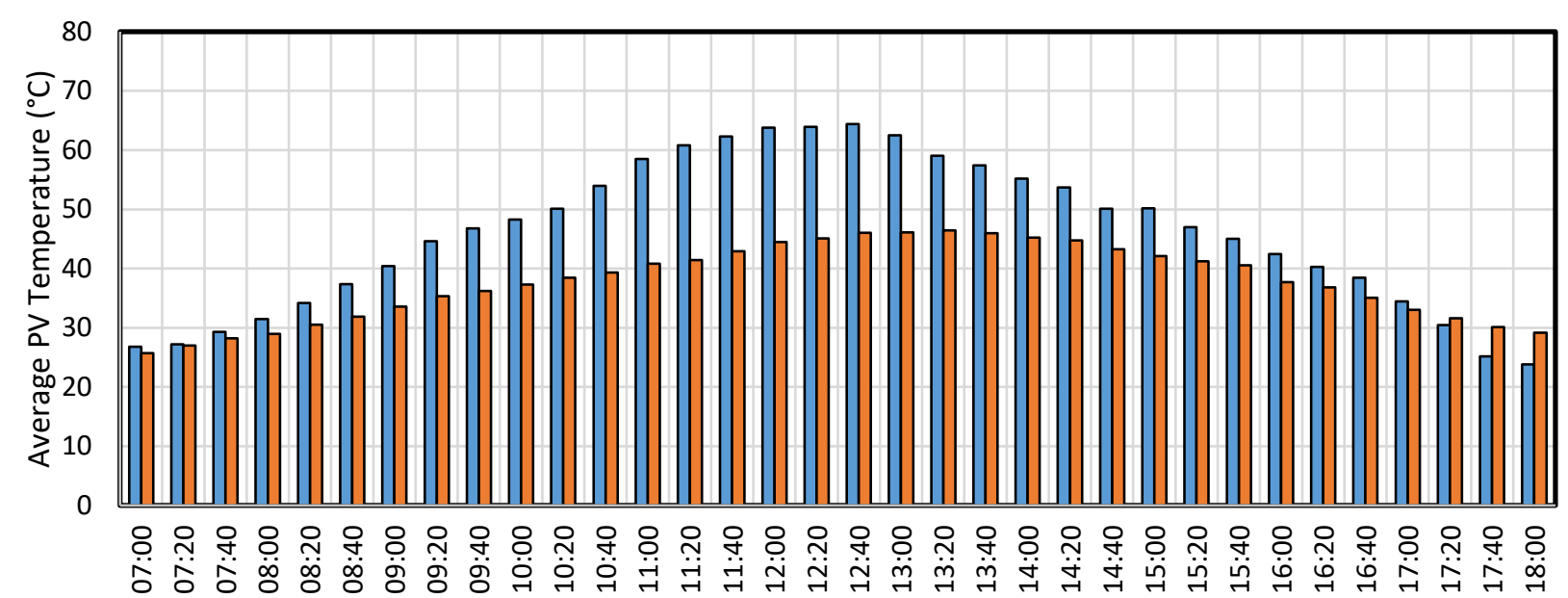

Time (h)

$\square$ Reference PV $\square$ PCM Cooled PV

(a)

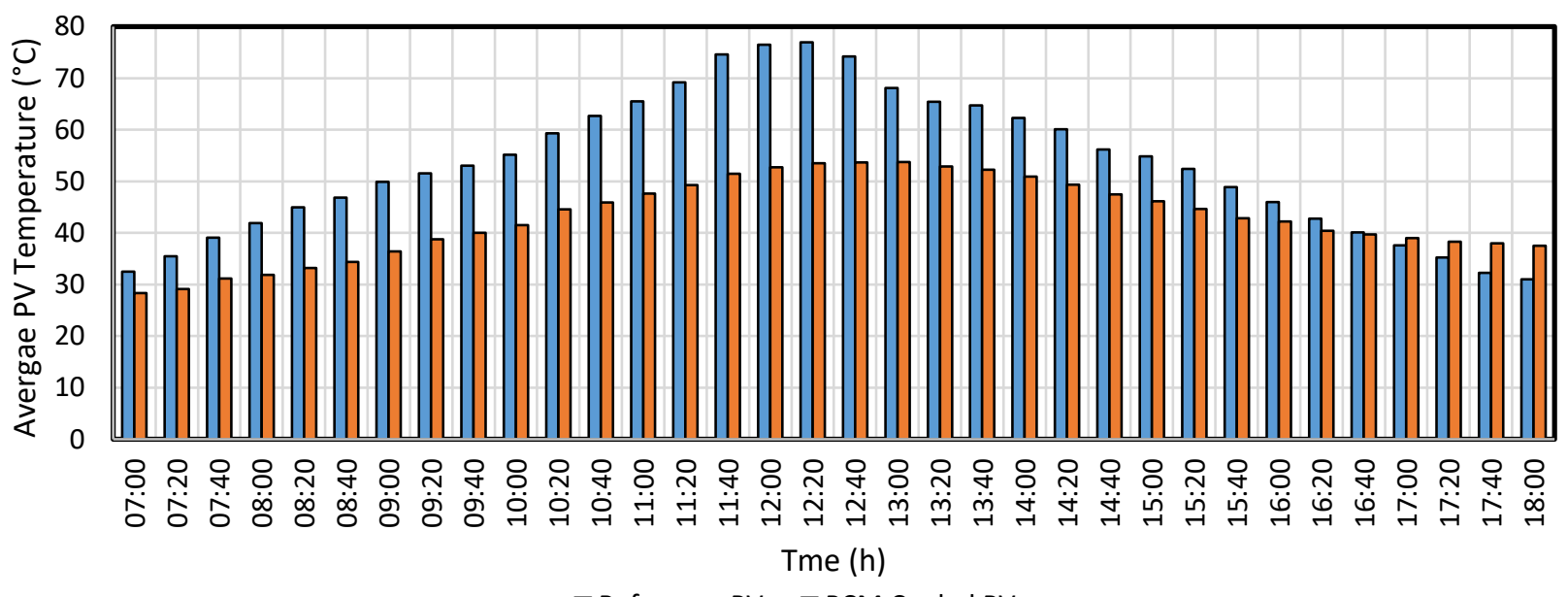

口Reference PV $\square$ PCM Cooled PV

(b)

Fig. 8. Temperature of reference ( $\left.\mathrm{PV}_{\text {ref }}\right)$ and PCM cooled PV panel $\left(\mathrm{PV}_{\mathrm{pcm}}\right)$ during (a) January month and (b) June month 


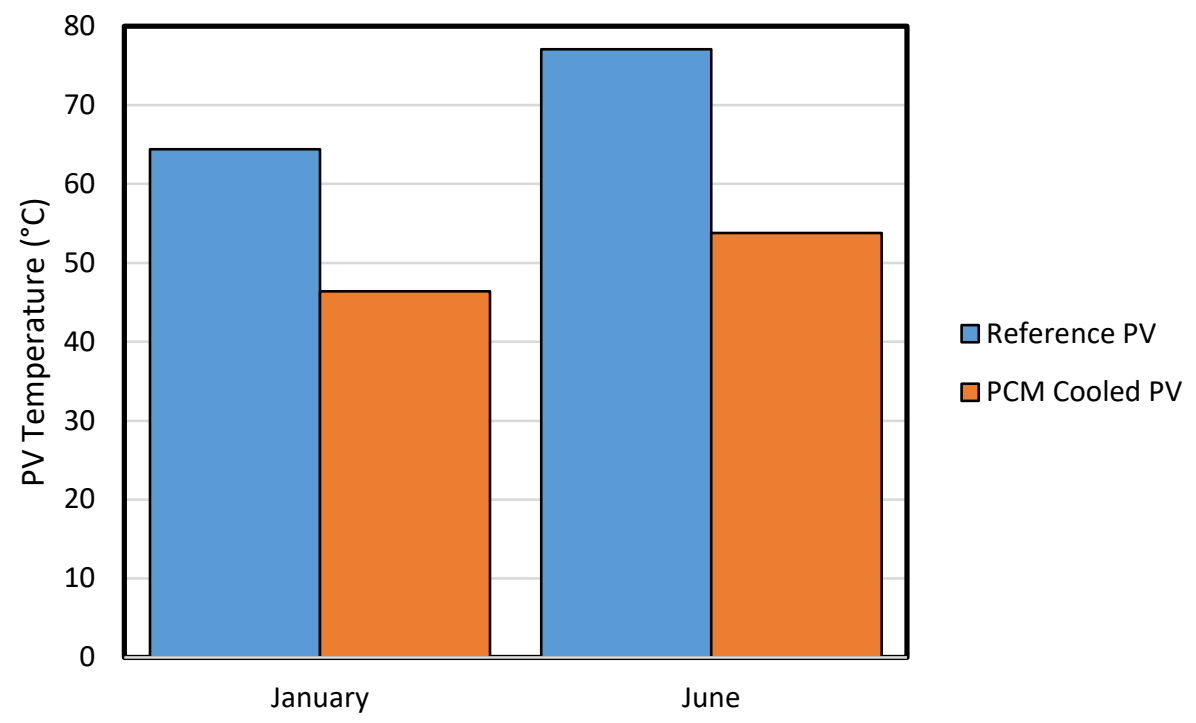

Fig. 9. Peak PV temperatures for PV-ref and PV-pcm panels for January and June months

\subsection{Open circuit voltage of PV panels}

The variations in the open circuit voltages $\left(\mathrm{V}_{\mathrm{oc}}\right)$ of the reference panel $(\mathrm{PV}$ ref $)$ and $\mathrm{PCM}$ cooled panel $\left(\mathrm{PV}_{\mathrm{pcm}}\right)$ from 7:00 hrs to 18:00 hrs for the month of January and June are shown in Figs. 10 (a) and 10 (b) respectively. It is observed that the $\mathrm{V}_{\mathrm{oc}}$ of the PCM integrated panel is more than that of the reference panel. This effect occurred because as the cell temperature of the $P V_{\text {pcm }}$ starts to rise, the multiple aluminium containers start absorbing the heat from the panel and dissipate the heat to the phase change material and to the environment. Because of the multiple aluminium containers, rate of heat dissipation is high and PCM was able to store heat for the longer duration. The combined effect of PCM and multiple containers maintain the $\mathrm{PV}_{\mathrm{pcm}}$ temperature lower and hence results in higher $\mathrm{V}_{\mathrm{oc}}$ compared to reference panel.

During noon, the open circuit voltages for PV-ref and PV-pcm panels for January and June months are shown in Fig. 11. The open circuit voltages attained by the reference and PCM cooled panels for the month of January are $24.3 \mathrm{~V}$ and $26.4 \mathrm{~V}$ respectively. For the month of June, the open circuit 
voltages attained by the reference and PCM cooled panels are $23.6 \mathrm{~V}$ and $26.0 \mathrm{~V}$ respectively. It is observed that the open circuit voltages are lesser in June. This is because of the reason that the cell temperature of the PV is higher in the month of June which leads to lesser open circuit voltage.

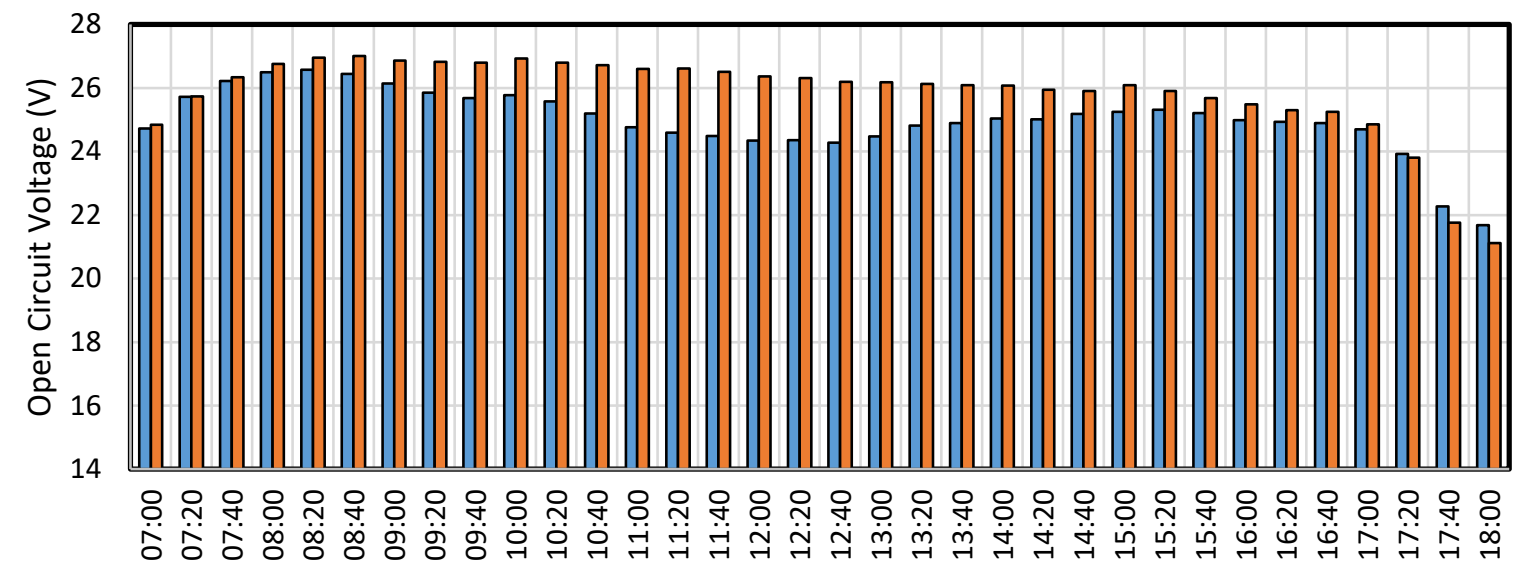

Time (h)

$\square$ Reference PV $\square$ PCM Cooled PV

(a)

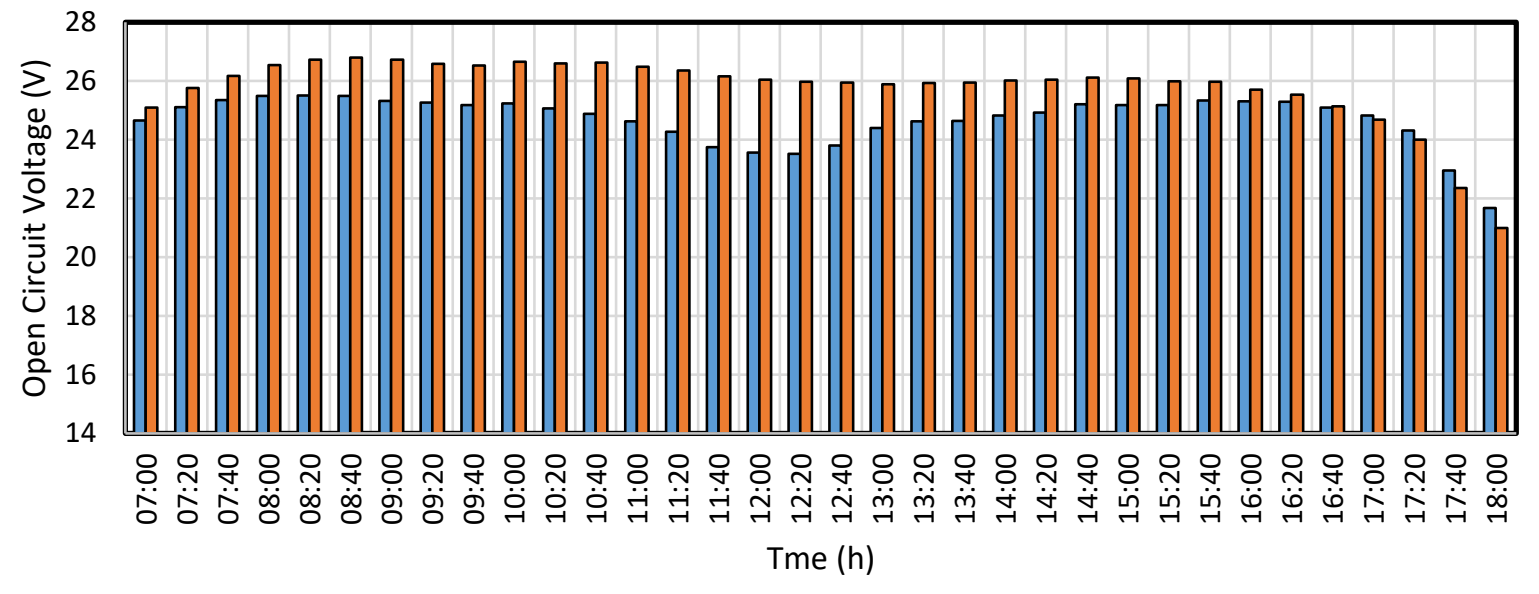

$\square$ Reference PV $\quad \square$ PCM Cooled PV

(b)

Fig. 10. Open circuit voltage of reference $\left(\mathrm{PV}_{\text {ref }}\right)$ and $\mathrm{PCM}$ cooled $\mathrm{PV}$ panel $\left(\mathrm{PV}_{\mathrm{pcm}}\right)$ during (a) January month (b) June month 


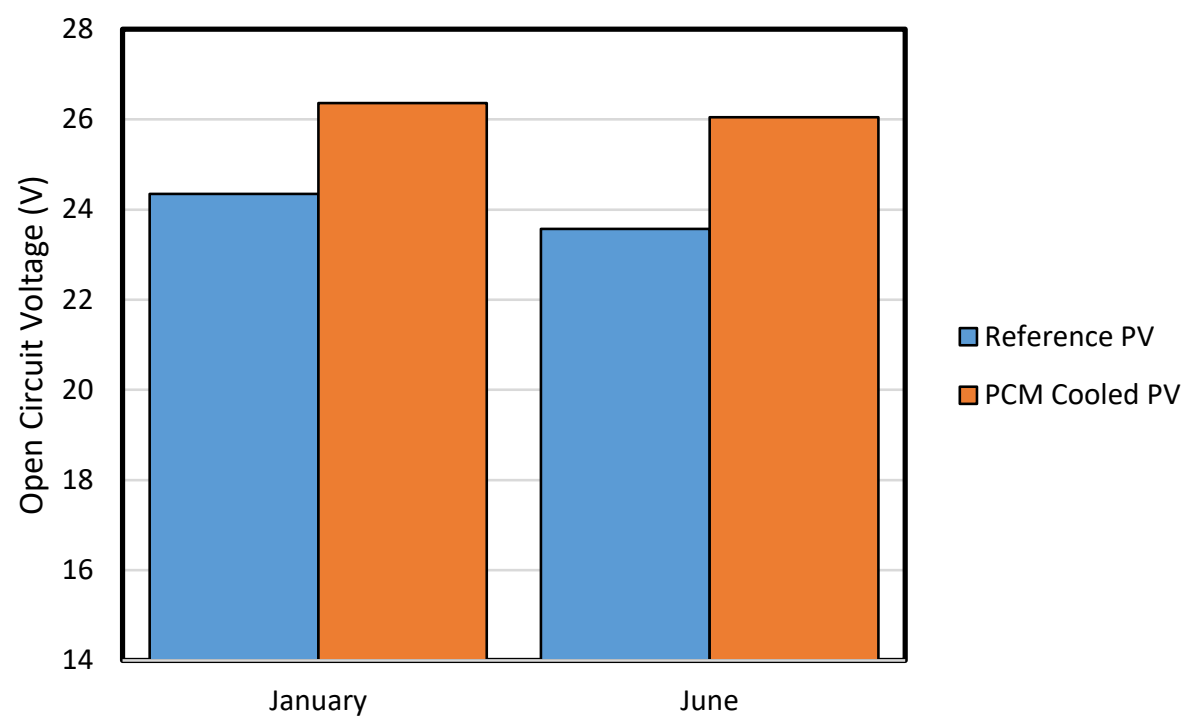

Fig. 11. Open circuit voltages for PV-ref and PV-pcm panel for January and June months during noon

\subsection{Short circuit current of PV panels}

The variations in the short circuit current $\left(I_{s c}\right)$ for the reference PV panel and PCM cooled PV panel during the experimental hours are shown in Figs. 12 (a) and 12 (b) for the month of January and June respectively. The graphs illustrate that the short circuit current increases with time, attain maximum values near to noon and then decreases. It is because of the fact that the short circuit current increases with increase in the solar irradiance. The peak values of short circuit current of PV-ref and PV-pcm panels for January and June months are shown in Fig. 13. The maximum short circuit current attained by the reference and PCM cooled panels for the month of January are 6.02A and 5.96A respectively. For the month of June, the maximum short circuit current attained by the reference and PCM cooled panels are 8.15A and 8.06A respectively. It is observed that the short circuit current values are higher in June. This is because of the reason that the solar irradiance is higher in the month of June which leads to higher short circuit current. 
It can be observed that the short circuit current of the PCM cooled panel is slightly lesser than that of the reference panel. This is because of the reason that the cell temperature of the $\mathrm{PV}_{\mathrm{pcm}}$ panel is lower than that of the reference panel which slightly reduces the short circuit current of the $\mathrm{PV}_{\mathrm{pcm}}$ panel.

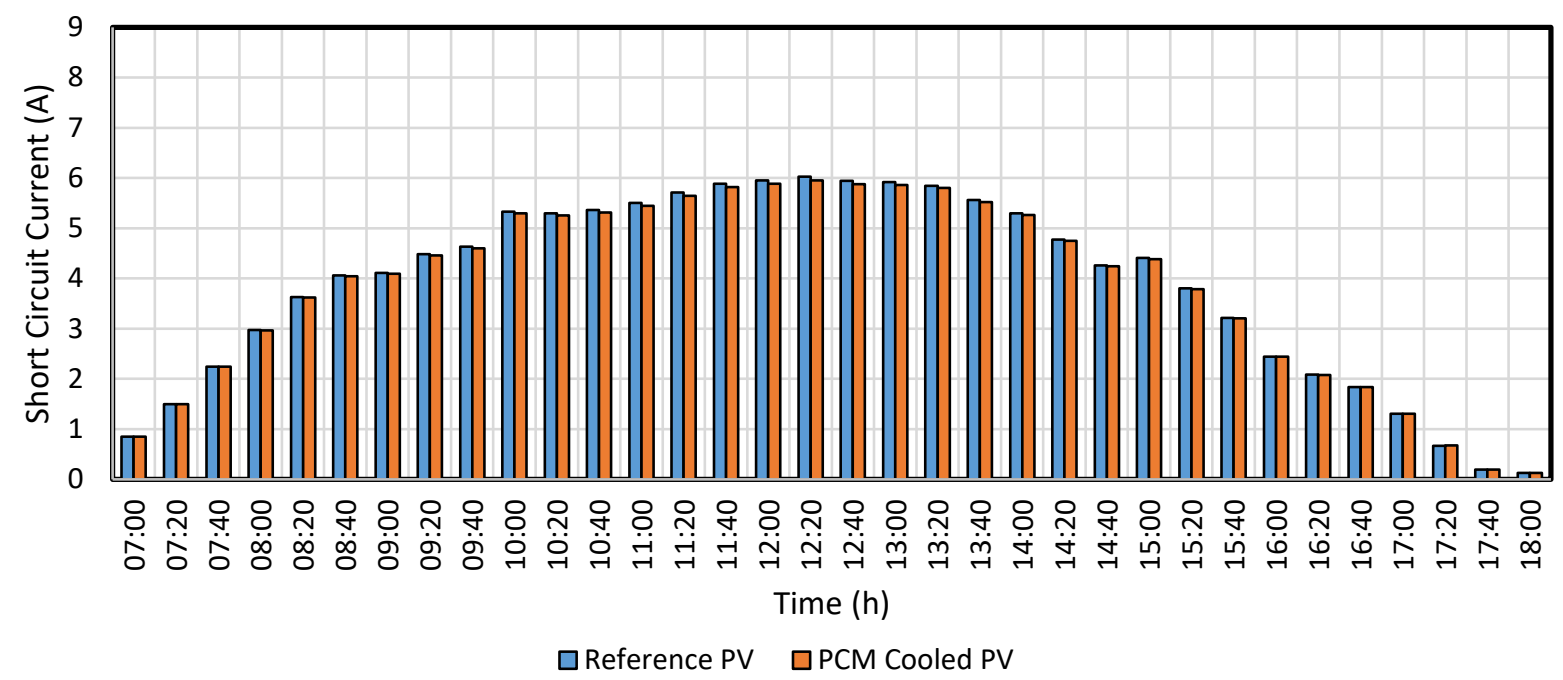

(a)

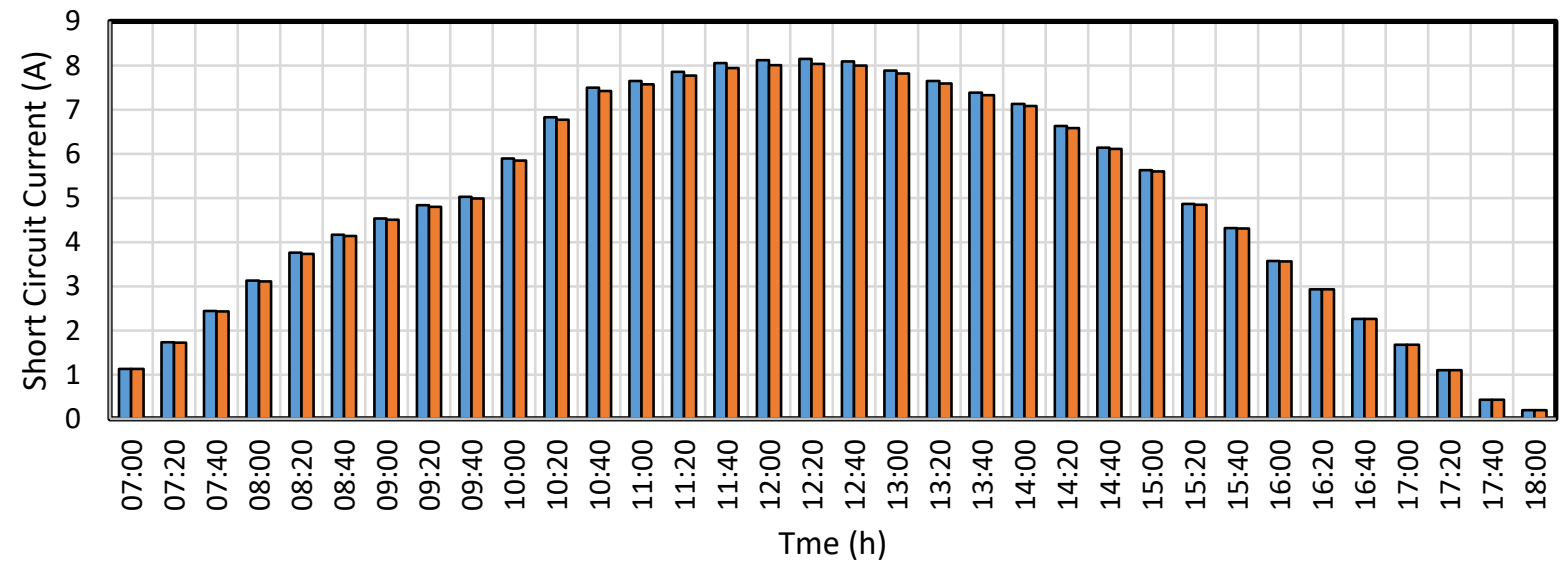

$\square$ Reference PV $\quad \square$ PCM Cooled PV

(b)

Fig. 12. Short circuit current $\left(\mathrm{I}_{\mathrm{sc}}\right)$ of reference $(\mathrm{PV}$ ref $)$ and $\mathrm{PCM}$ cooled $\mathrm{PV}$ panel $\left(\mathrm{PV} \mathrm{pcm}_{\mathrm{pcm}}\right)$ during

(a) January month (b) June month 


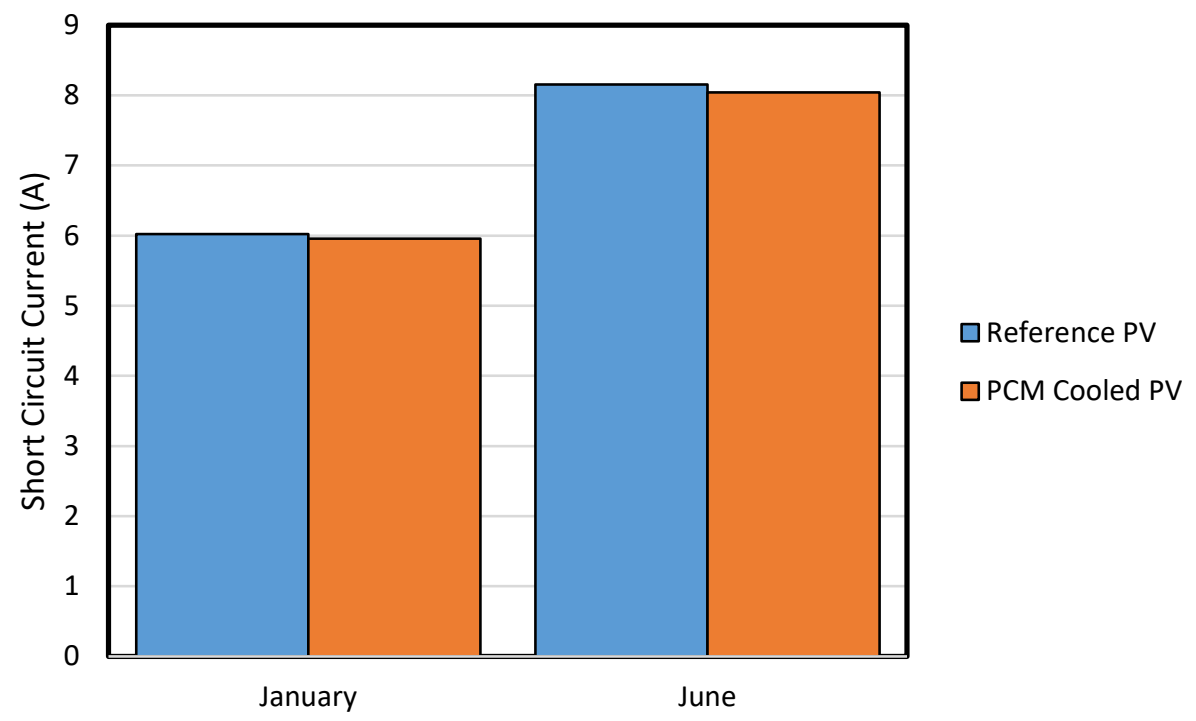

Fig. 13. Peak values of short circuit current for PV-ref and PV-pcm panel for January and June months

\subsection{Power output of PV panels}

The variations in power outputs of $\mathrm{PV}_{\text {ref }}$ and $\mathrm{PV}_{\mathrm{pcm}}$ panels with time for January and June have been shown in the Fig. 14(a) and Fig. 14(b) respectively. It can be observed from the figures that the power outputs of both the panels increase with increase in solar intensity, reach maximum value and thereafter decrease with profile similar to solar intensity. It is because of the fact that the elevation in the solar irradiance increases the current generation in the cells which increases the power output. The peak power outputs of PV-ref and PV-pcm panels for January and June months are shown in Fig. 15. The maximum power outputs attained by the reference and PCM cooled panels for the month of January are $99.5 \mathrm{~W}$ and $110.3 \mathrm{~W}$ respectively. For the month of June, the maximum power outputs attained by the reference and PCM cooled panels are $127.6 \mathrm{~W}$ and 143.5W respectively. It has been observed that the power output of the $\mathrm{PV}_{\mathrm{pcm}}$ panel is higher than that of the $\mathrm{PV}_{\text {ref }}$ panel which can also be seen from the results of Singh et al. [17]. The higher 
power output of the $\mathrm{PV}_{\mathrm{pcm}}$ panel is due to the lower $\mathrm{PV}$ temperature maintained by extraction of heat by phase change material with multiple conductivity-enhancing-containers.

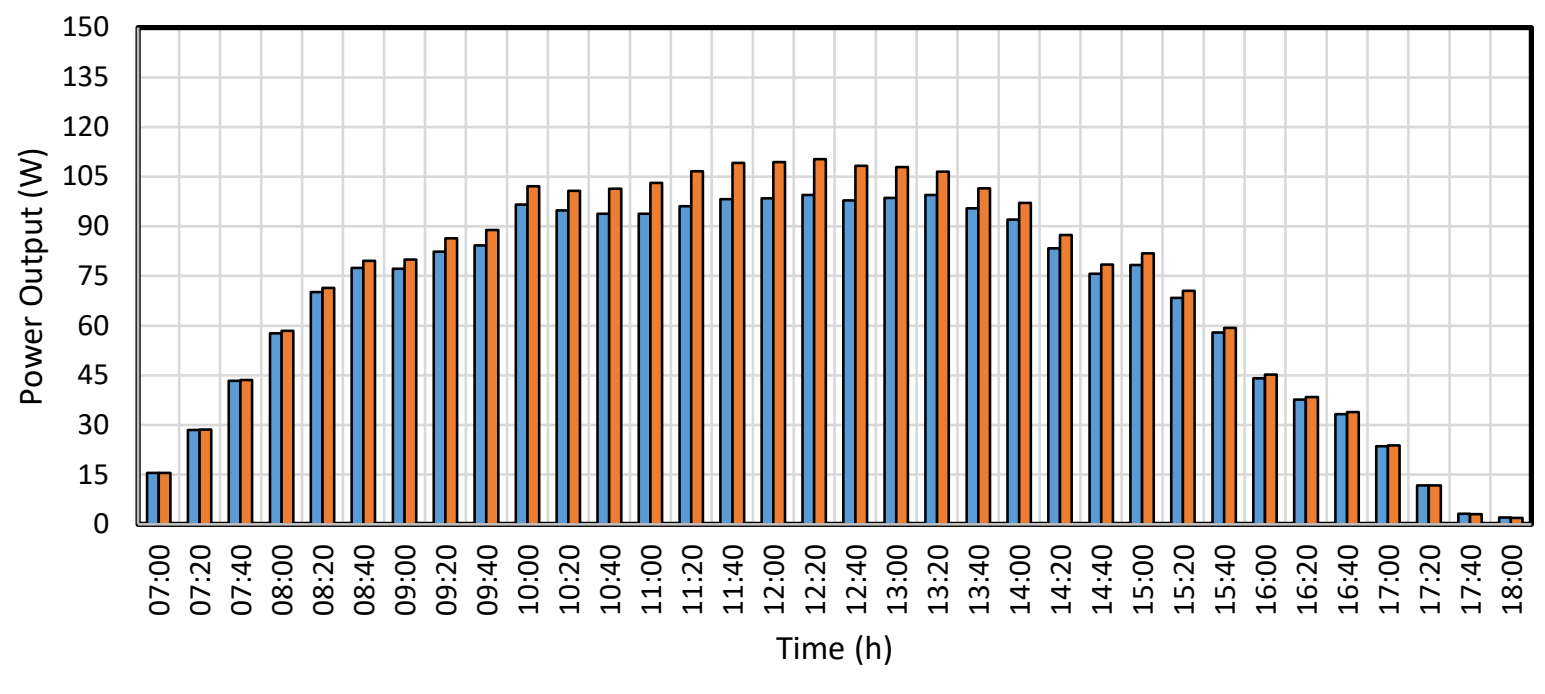

$\square$ Reference PV $\quad \square$ PCM Cooled PV

(a)

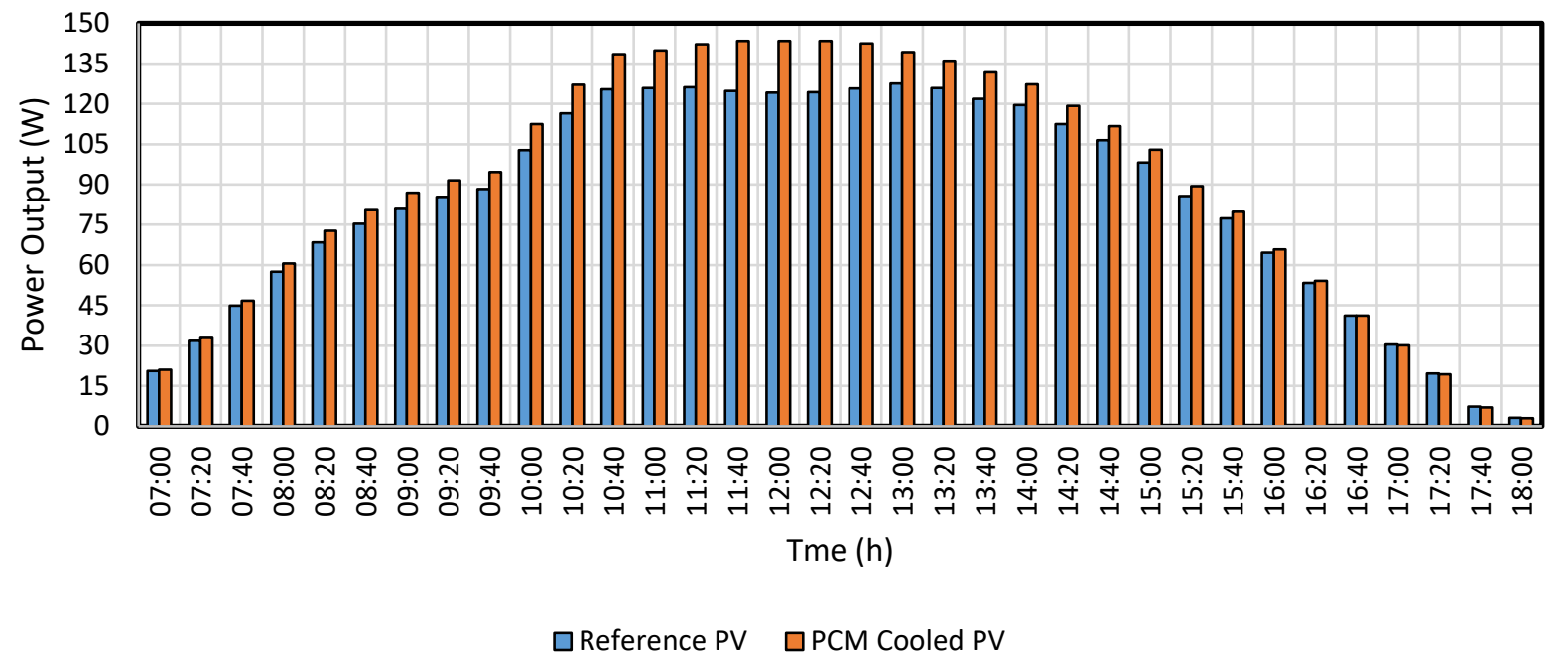

(b)

Fig. 14. Power output of reference ( $\left(\mathrm{PV}_{\text {ref }}\right)$ and $\mathrm{PCM}$ integrated $\mathrm{PV}$ panel $\left(\mathrm{PV}_{\mathrm{pcm}}\right)$ during (a) January month and (b) June month 


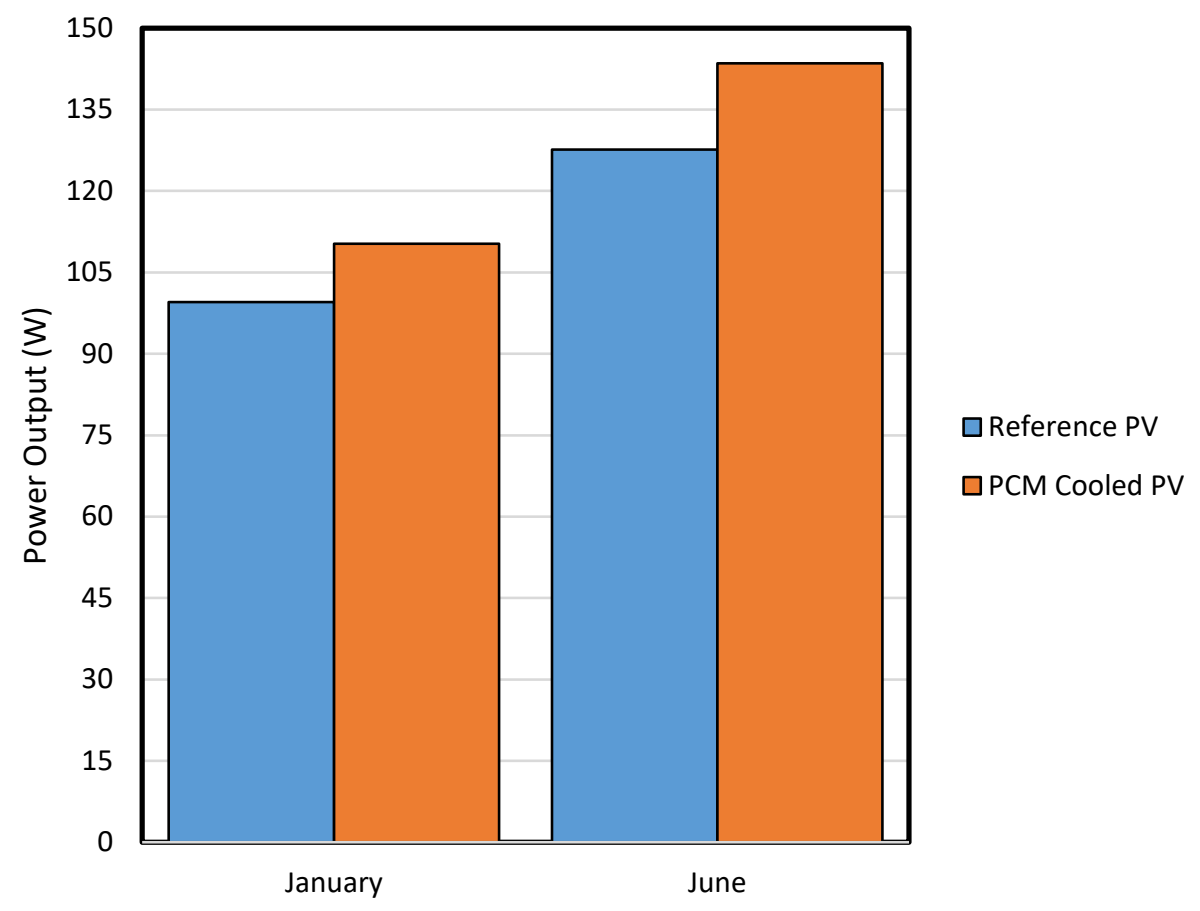

Fig. 15. Peak values of power output for PV-ref and PV-pcm panel for January and June months

\subsection{Current-Voltage and Power-Voltage curves of PV panels}

The Current-Voltage (I-V) and Power-Voltage (P-V) curves of $\mathrm{PV}_{\text {ref }}$ and $\mathrm{PV}_{\mathrm{pcm}}$ panels for January and June (during noon) have been shown in the Fig. 16(a) and Fig. 16(b) respectively. It has been observed that the fill factor increases from 0.678 to 0.705 for January and 0.649 to 0.688 for June. The curves also show that the power output and open circuit voltage of the $\mathrm{PV}_{\mathrm{pcm}}$ panel are higher than that of the $\mathrm{PV}_{\text {ref }}$ panel. It is due to the lower $\mathrm{PV}$ temperature maintained by extraction of heat by phase change material with multiple conductivity-enhancing-containers. 


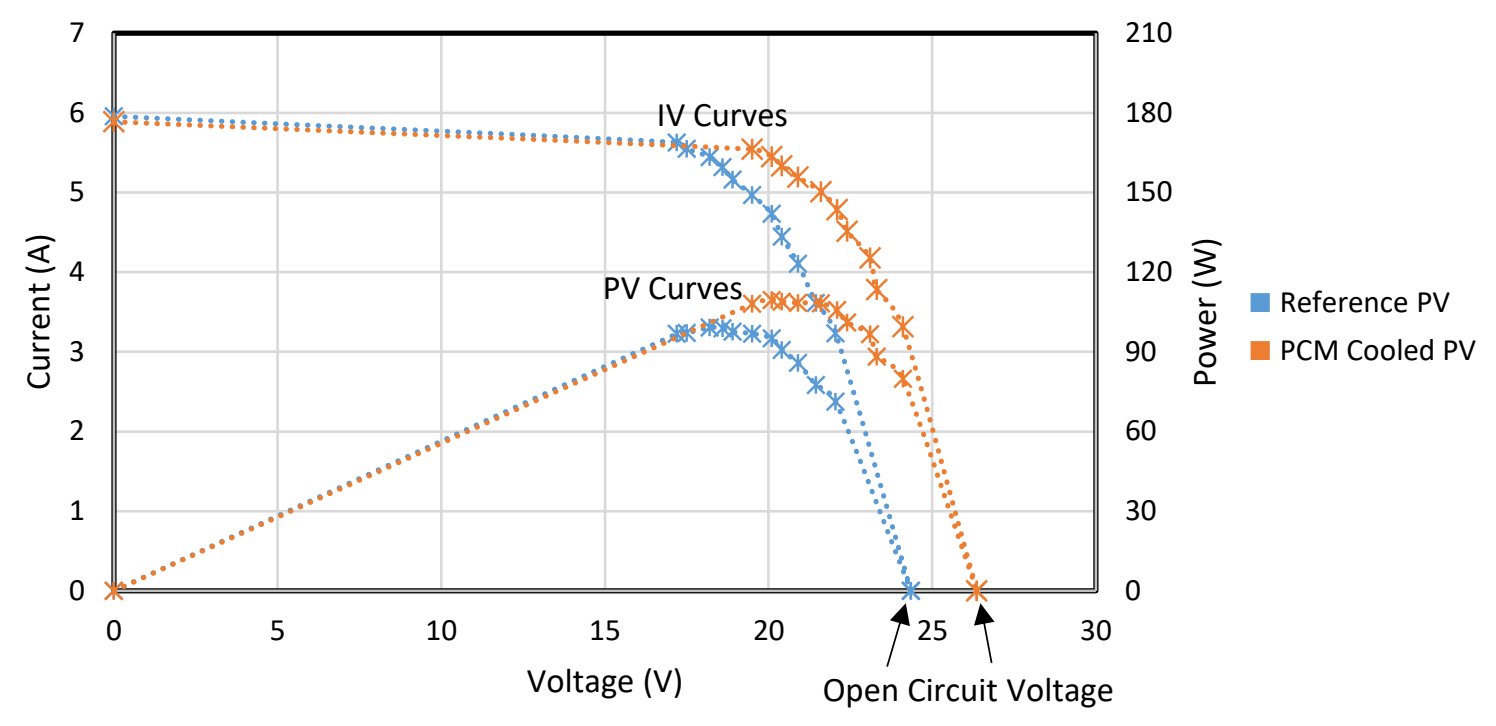

(a)

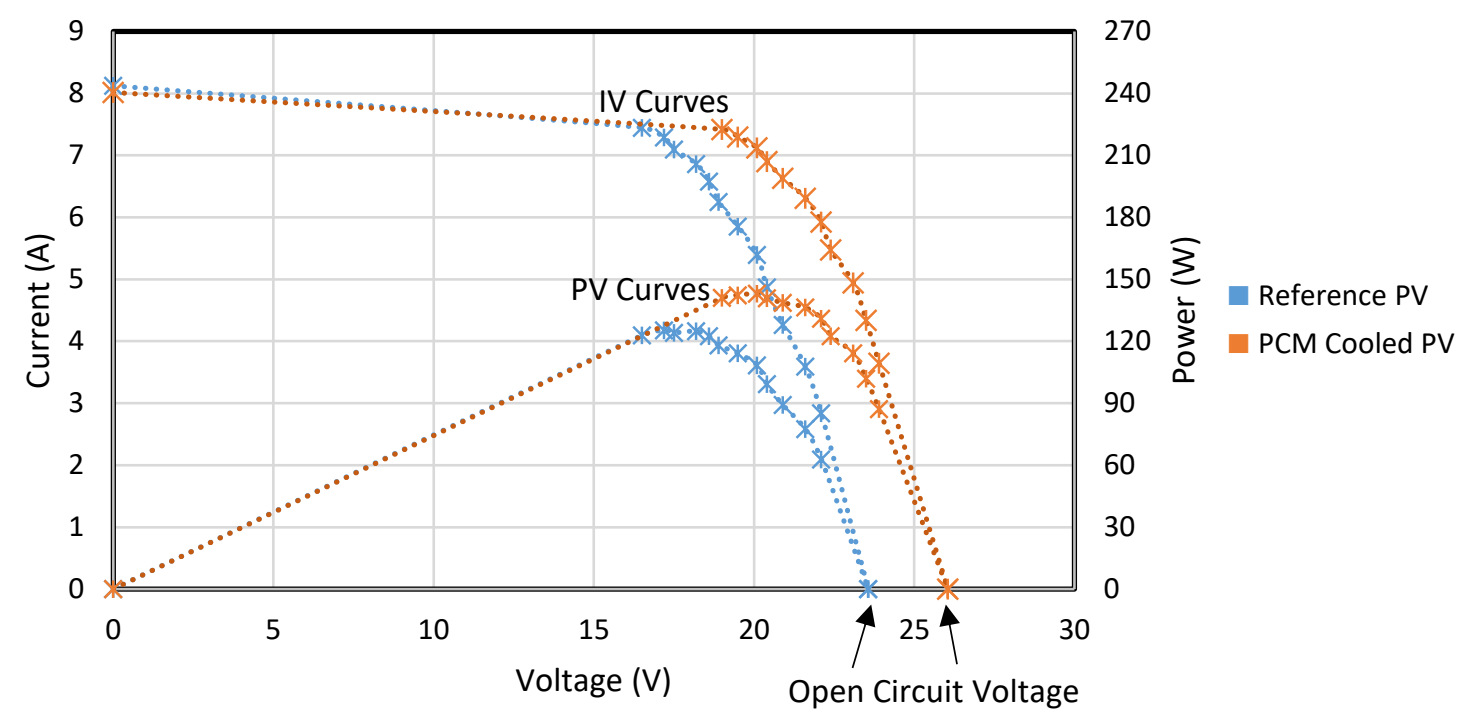

(b)

Fig. 16. Current-Voltage (I-V) and Power-Voltage (P-V) curves during noon of reference ( $\left.\mathrm{PV}_{\text {ref }}\right)$ and PCM integrated PV panel $\left(\mathrm{PV}_{\mathrm{pcm}}\right)$ during (a) January month and (b) June month 


\subsection{Electrical efficiencies of the PV panels}

The variations in the electrical efficiency of $\mathrm{PV}_{\text {ref }}$ and $\mathrm{PV}_{\mathrm{pcm}}$ panels from 7:00 $\mathrm{h}$ to $18: 00 \mathrm{~h}$ for the month of January and June are shown in Figs. 17 (a) and 17 (b) respectively. It is observed that, initially, the efficiency of the panels increase with time. It is because of increase in irradiance that has positive effect on the efficiency. Around noon, the efficiency decreases. It is because of increase in PV temperature that negatively affects the efficiency. During the end of the day, the efficiency decreases with time. It is because of decrease in irradiance.

During noon, the efficiency attained by the reference and PCM cooled panels for the month of January are $9.5 \%$ and $10.5 \%$ respectively. For the month of June, the efficiency attained by the reference and PCM cooled panels are $8.8 \%$ and $10.2 \%$ respectively. It is observed that the efficiency of PCM integrated panel is more than that of the reference panel. The higher electrical efficiency of the $\mathrm{PV}_{\mathrm{pcm}}$ panel is due to the higher power production resulting from the thermal management of PV by using phase change material along with multiple conductivity-enhancingcontainers.

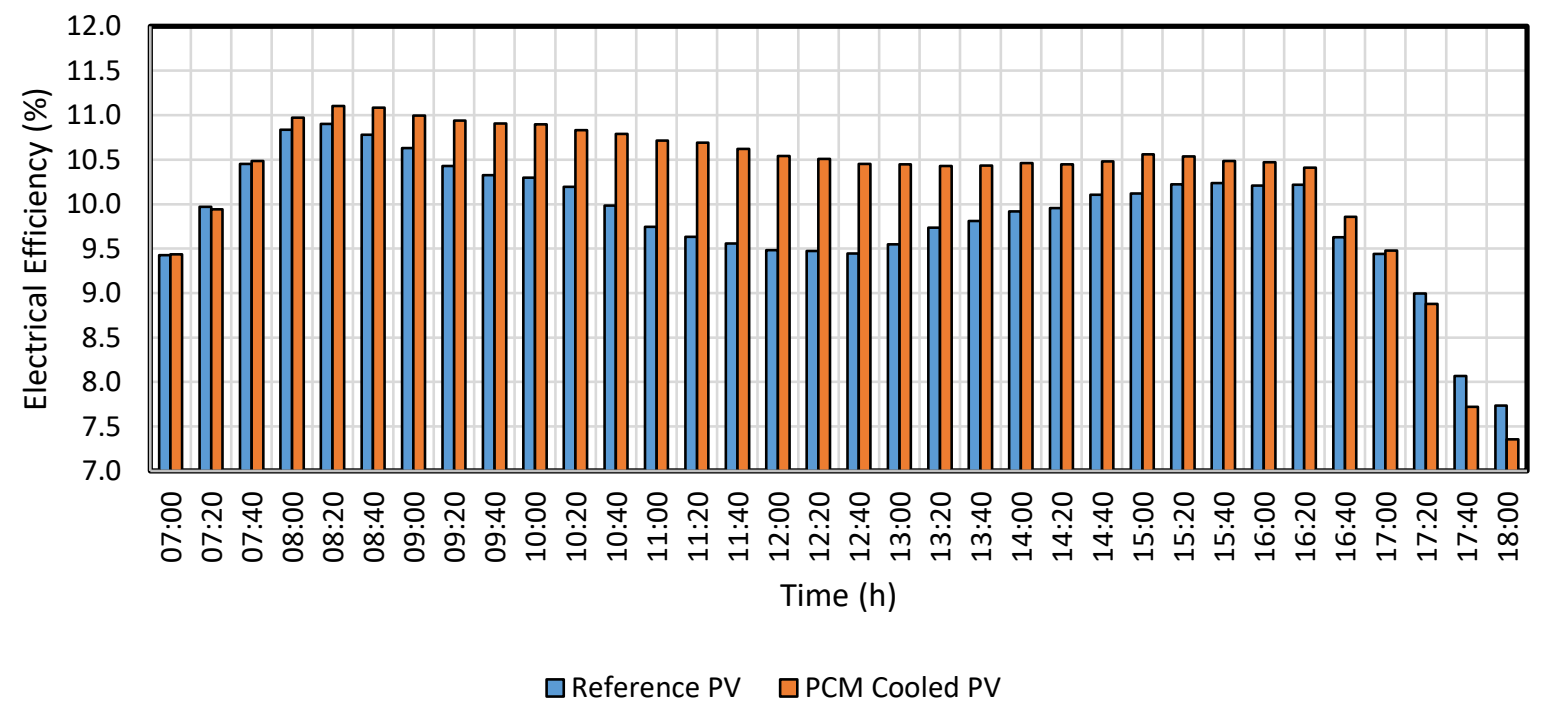

(a) 


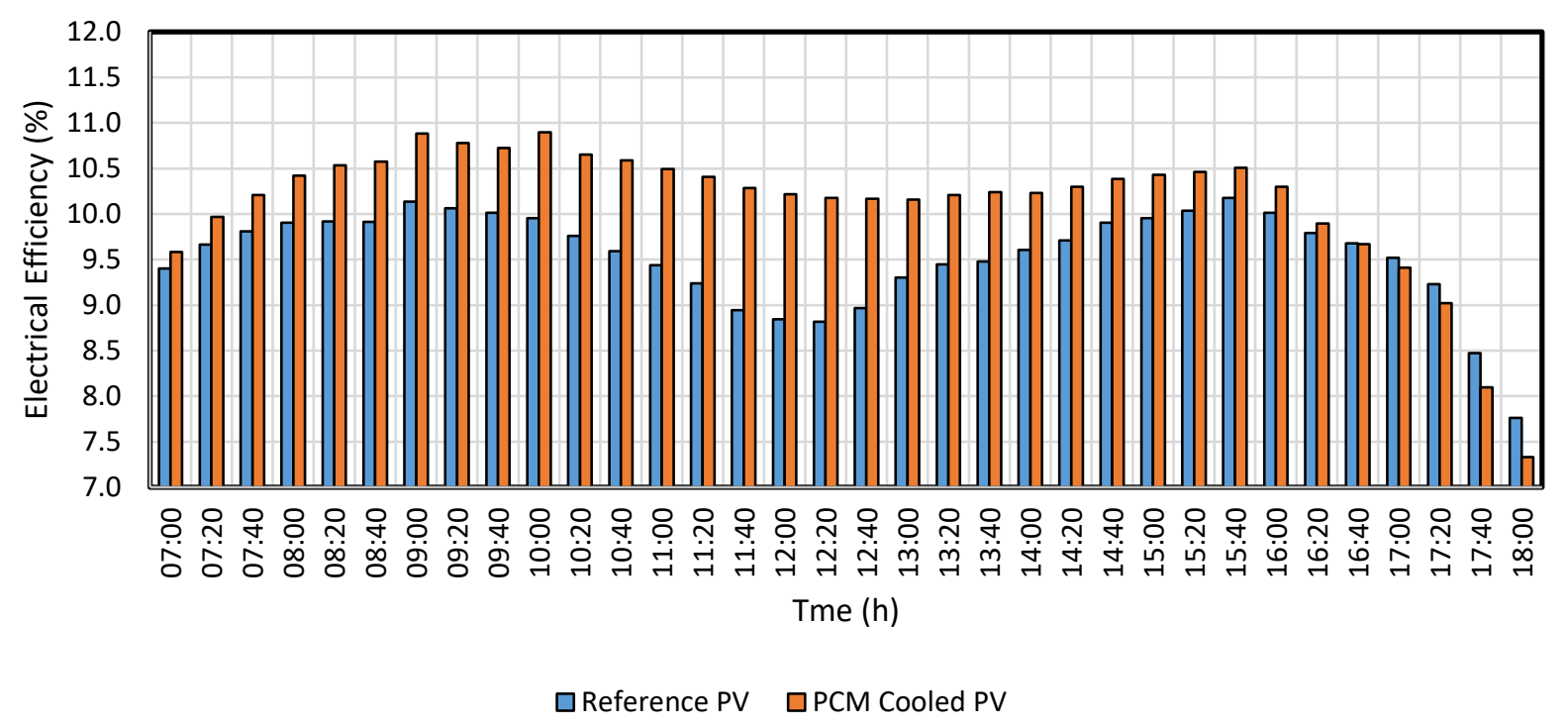

(b)

Fig. 17. Electrical efficiency of reference $\left(P V_{\text {ref }}\right)$ and $P C M$ integrated $P V$ panel $\left(P V_{p c m}\right)$ during (a) January month and (b) June month

\subsection{Daily electrical energy generated and conversion efficiency}

Total electrical energy generated by reference PV panel and PCM cooled PV panel for complete day for the month of January and June are shown in Fig. 18. The results show that the electrical energy generation by $\mathrm{PV}_{\mathrm{pcm}}$ was $817 \mathrm{Wh} /$ day during January and $1026 \mathrm{Wh} /$ day during June. The respective electrical energy generation by $\mathrm{PV}_{\text {ref }}$ was $769 \mathrm{Wh} /$ day during January and $948 \mathrm{Wh} /$ day during June. Thus, the PCM has increased the electrical energy generation from PV by $6.2 \%$ and $8.3 \%$ in January and June respectively (Table 5). Thus, PCM is more productive in summers as compared to winters which was also reported by other researchers $[8,31]$. 


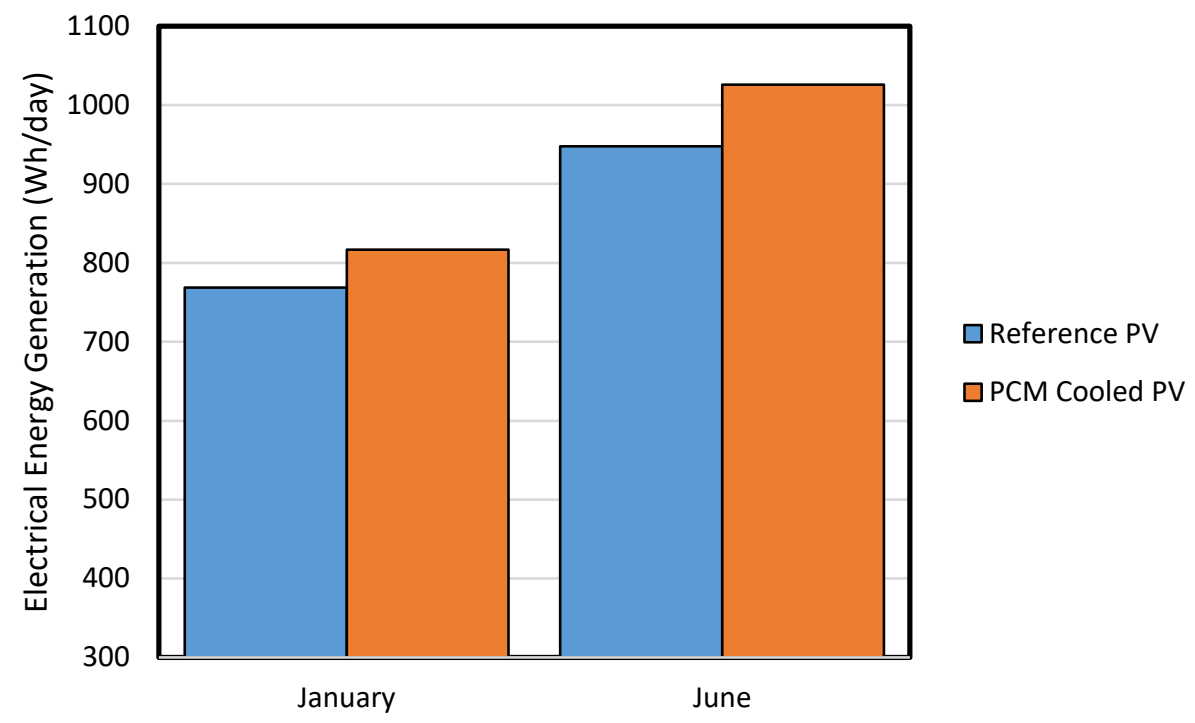

Fig. 18. Electrical energy generated by PV-ref and PV-pcm panels for January and June months

Table 5 Comparative analysis of reference PV and PV PCM panels during noon

\begin{tabular}{|c|c|c|c|c|c|c|c|c|}
\hline \multirow{3}{*}{ Month } & \multirow{3}{*}{ Panel } & \multirow{2}{*}{$\begin{array}{l}\text { Average PV } \\
\text { Temperature }\end{array}$} & \multirow{2}{*}{$\begin{array}{l}\text { Open } \\
\text { Circuit }\end{array}$} & \multirow{2}{*}{$\begin{array}{l}\text { Short } \\
\text { circuit }\end{array}$} & \multirow{2}{*}{$\begin{array}{c}\text { Fill } \\
\text { Factor }\end{array}$} & \multirow{2}{*}{$\begin{array}{l}\text { Power } \\
\text { Output }\end{array}$} & \multirow{2}{*}{$\begin{array}{c}\text { Daily Electrical } \\
\text { Energy }\end{array}$} & \multirow{2}{*}{$\begin{array}{c}\text { Increase in } \\
\text { electricity using }\end{array}$} \\
\hline & & & & & & & & \\
\hline & & & Voltage & current & & & Generation & proposed system \\
\hline & $\mathrm{PV}_{\text {ref }}$ & $64.4^{\circ} \mathrm{C}$ & $24.3 \mathrm{~V}$ & $6.02 \mathrm{~A}$ & 0.678 & $99.5 \mathrm{~W}$ & $769 \mathrm{Wh}$ & - \\
\hline & $\overline{\mathrm{PV}} \mathrm{PCM}_{\mathrm{PCM}}$ & $46.4^{\circ} \mathrm{C}$ & $26.4 \mathrm{~V}$ & $5.96 \mathrm{~A}$ & 0.705 & $110.3 \mathrm{~W}$ & $817 \mathrm{Wh}$ & $6.2 \%$ \\
\hline
\end{tabular}

January

\begin{tabular}{lccccccc}
$\mathrm{PV}_{\text {ref }}$ & $77.1^{\circ} \mathrm{C}$ & $23.6 \mathrm{~V}$ & $8.15 \mathrm{~A}$ & 0.649 & $127.6 \mathrm{~W}$ & $948 \mathrm{Wh}$ & - \\
\hline $\mathrm{PV} \mathrm{PCM}$ & $53.8^{\circ} \mathrm{C}$ & $26.0 \mathrm{~V}$ & $8.06 \mathrm{~A}$ & 0.688 & $143.5 \mathrm{~W}$ & $1026 \mathrm{Wh}$ & $8.3 \%$
\end{tabular}

June 


\subsection{PCM Payback Period}

The cost incurred for the purchasing of PCM was INR 30/kg and the amount of the used PCM was $60 \mathrm{~kg}$. Thus, the total cost of PCM was INR1800. An additional cost of INR 2500 was for aluminum containers considering bulk purchasing. Thus, the total cost of PCM containers was around INR 4300. Taking an average of January and June values, a very simple estimate of the cost savings due to PCM by producing extra electricity generation will be INR184/year. Thus, PCM containers have payback period of around 23 years. It must be mentioned that the use of the heat stored in PCM for some application and the mass production of this technology can significantly reduce the payback period.

\section{Conclusions}

In the present study, the PCM based PV cooling was enhanced by using multiple conductivity enhancing aluminium containers. For Chennai climate, the results showed that the proposed technique was able to reduce the maximum PV panel temperature by $18.0^{\circ} \mathrm{C}$ for January month and $23.3^{\circ} \mathrm{C}$ for June month by using widely available PCM (Calcium chloride hexahydrate). The daily electricity generation increased by $6.2 \%$ for January and $8.3 \%$ for June.

It must be mentioned that the heat extracted by PCM (from PV) was not used for any application in the present study. The heat can be used for water heating application by integrating heat exchanger inside the PCM containers and for space heating application in cold countries. It will enhance the overall efficiency of the system through useful thermal output in addition to increment in daily electricity generation. It will also help in reducing the payback period of the PCM. 


\section{Acknowledgement}

The financial support provided by EPSRC funded project (RESCUES (EP/K03619X/1) and Department of Science and Technology (DST, Govt. of India), New Delhi through the technology development project, (Grant No.: DST/RCUK/SEGES/2012/04 (G)) is acknowledged

\section{References}

[1] Maji P., Kandlikar M. Quantifying the air quality, climate and equity implications of India's household energy transition. Energy for Sustainable Development 55 (2020) 37-47.

[2] Gielen D., Boshell F., Saygin D., Bazilian M. D., Wagner N., Gorini R. The role of renewable energy in the global energy transformation. Energy Strategy Reviews 24 (2019) $38-50$.

[3] Adams S., Klobodu E.K.M., Apio A. Renewable and non-renewable energy, regime type and economic growth. Renewable Energy 125 (2018) 755-767.

[4] Helm C, Mier M. On the efficient market diffusion of intermittent renewable energies. Energy Economics 80 (2019) 812-830.

[5] Hansen K., Breyer C., Lund H. Status and perspectives on 100\% renewable energy systems. Energy 175 (2019) 471-480.

[6] Trindade A., Cordeiro L. Automated formal verification of stand-alone solar photovoltaic systems. Solar Energy 193 (2019) 684-691.

[7] Yuan W., Ji J., Li Z., Zhou F., Ren X., Zhao X, Liu S. Comparison study of the performance of two kinds of photovoltaic/thermal(PV/T) systems and a PV module at high ambient temperature. Energy 148 (2018) 1153-1161.

[8] Ma T., Li Z., Zhao J. Photovoltaic panel integrated with phase change materials (PV-PCM): technology overview and materials selection. Renewable and Sustainable Energy Reviews 116 (2019) 109406.

[9] Kasaeian A., Khanjari Y., Golzari S., Mahian O., Wongwises S. Effects of forced convection on the performance of a photovoltaic thermal system: An experimental study. Experimental Thermal and Fluid Science 85 (2017) 13-21.

[10] Barone G., Buonomano A., Forzano C., Palombo A., Panagopoulos O. Photovoltaic thermal collectors: Experimental analysis and simulation model of an innovative low-cost water-based prototype. Energy 179 (2019) 502-516. 
[11] Yuan W., Ji J., Li Z., Zhou F., Ren X., Zhao X, Liu S. Comparison study of the performance of two kinds of photovoltaic/thermal(PV/T) systems and a PV module at high ambient temperature. Energy 148 (2018) 1153-1161.

[12] Chandrasekar M., Senthilkumar T. Experimental demonstration of enhanced solar energy utilization in flat PV (photovoltaic) modules cooled by heat spreaders in conjunction with cotton wick structures. Energy 90 (2015) 1401-1410.

[13] Li G., Shittu S., Diallo T.M.O., Yu M., Zhao X., Ji J. A review of solar photovoltaicthermoelectric hybrid system for electricity generation. Energy 158 (2018) 41-58.

[14] Khanna S., Newar S., Sharma V., Reddy K.S., Mallick T.K., Radulovic J., Khusainov R., Hutchinson D., Becerra V. Electrical enhancement period of solar photovoltaic using phase change material. Journal of Cleaner Production 221 (2019) 878-884.

[15] Reddy K.S., Mudgal V., Mallick T.K. Review of latent heat thermal energy storage for improved material stability and effective load management. J Energy Storage 15 (2018) 205-227.

[16] Rezvanpour M., Borooghani D., Torabi F., Pazoki M. Using $\mathrm{CaCl}_{2} 6 \mathrm{H}_{2} \mathrm{O}$ as a phase change material for thermo-regulation and enhancing photovoltaic panels' conversion efficiency: Experimental study and TRNSYS validation. Renewable Energy 146 (2020) 1907-1921.

[17] Singh P., Khanna S., Becerra V., Newar S., Sharma V., Mallick T.K., et al. Power improvement of finned solar photovoltaic phase change material system. Energy 193 (2020) 116735.

[18] Huang M.J., Eames P.C., Norton B. Thermal regulation of building-integrated photovoltaics using phase change materials. Int J Heat Mass Transf 47 (2004) 2715-2733.

[19] Rabie R., Emam M., Ookawara S., Ahmed M. Thermal management of concentrator photovoltaic systems using new configurations of phase change material heat sinks. Solar Energy 183 (2019) 632-652.

[20] Souayfane F., Biwole P.H., Fardoun F. Melting of a phase change material in presence of natural convection and radiation: A simplified model. Applied Thermal Engineering 130 (2018) 660-671.

[21] Ho C.J., Jou B.T., Lai C.M., Huang C.Y. Performance assessment of a BIPV integrated with a layer of water-saturated MEPCM. Energy and Buildings 67 (2013) 322-333. 
[22] Nada S.A., El-Nagar D. H., Hussein H. M. S. Improving the thermal regulation and efficiency enhancement of PCM Integrated PV modules using nano particles. Energy Conversion and Management 166 (2018) 735-743.

[23] Zarma I., Ahmed M., Ookawara S. Enhancing the performance of concentrator photovoltaic systems using Nanoparticle-phase change material heat sinks. Energy Conversion and Management 179 (2019) 229-242.

[24] Yin E., Li Q., Li D., Xuan Y. Experimental investigation on effects of thermal resistances on a photovoltaic-thermoelectric system integrated with phase change materials. Energy 169 (2019) 172-185.

[25] Klemm T., Hassabou A., Abdallah A., Andersen O. Thermal energy storage with phase change materials to increase the efficiency of solar photovoltaic modules. Energy Procedia 135 (2017) 193-202.

[26] Abdollahi N., Rahimi M. Potential of water natural circulation coupled with nanoenhanced PCM for PV module cooling. Renewable Energy 147 (2020) 302-309.

[27] Specification of photovoltic panel - SHARP NU-R5E3Z n.d. http://www.posharp.com/nur5e3z-solar-panel-from-sharp_p396969011d.aspx.

[28] Khanna S., Newar S., Sharma V., Reddy K.S., Mallick T.K. Optimization of fins fitted phase change material equipped solar photovoltaic under various working circumstances. Energy Conversion and Management 180 (2019) 1185-1195.

[29] Prodigit - Specification, model- 3311F Series (60V, 60A, 300W) DC Electronic Load n.d. http://www.prodigitusa.com/prodigit/image01/3311fSpec.jpg.

[30] Enterprises B. Buyyart Enterprises. Https://WwwBuyyartCom/Product/Buyyart-1pcsOriginal-Stars-Drg-102-10g-Cpu-Silicone-Thermal-Paste-Thermal-Grease-ThermalCompound/ n.d. https://www.buyyart.com/product/buyyart-1pcs-original-stars-drg-10210g-cpu-silicone-thermal-paste-thermal-grease-thermal-compound/.

[31] Ma T., Zhao J., Li Z. Mathematical modelling and sensitivity analysis of solar photovoltaic panel integrated with phase change material. Applied Energy 228 (2018) 1147-1158. 